\title{
Insularity And The UniQue Position Of Aeolic Song In Archaic GREEK POETRY
}

\author{
Tadeu Andrade ${ }^{1}$
}

\section{ABSTRACT}

Archaic Greek poetry was a multiple phenomenon: different areas developed diverse, though interrelated genres. This article comments on the unique position Aeolic mélos had in the archaic Greek song tradition. Firstly, it points to Sappho and Alcaeus' somewhat ambivalent reception by ancient authors. Secondly, it shows how different aspects of their corpus exhibit a pattern of communication with other Greek poetry, while maintaining its own particularities. This unique status is demonstrated by an analysis of Aeolic poetic formulae. Finally, the article proposes the insular geography of Lesbos as one of the reasons for the singularity of this poetry.

\section{KEYWORDS}

Insularity, Greek lyric, Lesbian poetry, Orality, Formulae.

1 Full Professor at Universidade Federal da Bahia, Salvador, Brazil. Email: tadeucostaandrade@yahoo.com.br. 


\section{Introduction ${ }^{2}$}

Archaic Greek poetry is noticeably a mixture of cultural variety and unity. Just as there was no single Greek language, in Greek literature one could find a whole range of poetic genres distributed in different dialects. Thus, the distinctive form of épos seen in Homer was a predominantly Ionian fruit, as were elegy and iambus ${ }^{3}$. Likewise, an important branch of mélos arose in Dorian lands, the earliest extant representative of which is Alcman, active in Sparta. At an early stage, some genres started not only to circulate throughout the Greek world, but also to be composed outside their original environments, by foreign poets. So, by the beginning of the 5 th $\mathrm{C} .^{4}$, Doric lyric had been performed by poets from Rhegium, Ceos and Thebes, none of which was of Dorian ethnicity. Epic poets, on their turn, had arisen in Cyprus, Lesbos, Boeotia, Corinth, and Cyrene. Finally, elegy had already been sung by Tyrtaeus and Theognis in Dorian póleis.

During their transcultural expansion, these genres retained not only their metre and conventions, but sometimes even their dialect. Extant epic and elegiac poems and fragments are all in Ionic, despite the origin of their poets. Lyricists from all over the Hellenic world made literary use of Doric dialect, despite some differences ${ }^{5}$. Some evidence suggests this phenomenon could have been the result of subsequent uniformization, when the poems were established in writing ${ }^{6}$. However, the adoption of Ionic by other ethnic groups was already a reality in the Archaic era, as evidenced by the

\footnotetext{
${ }^{2}$ Special thanks to Rafael Frate for the gentle language editing of this article.

3 The statement holds even if we presuppose a previous, prehistoric, Aeolic phase of epic. If the Ionic tradition was not the first form of epic to exist in Greek language, still, Homer's metre and dialect are distinctively Ionic. On the origins of Ionic metrical forms, see West (1973). For a different explanation of the origins of the hexameter, see Nagy (1974, pp. 49-102). For arguments for and against the existence of an Aeolic phase, see Horrocks (1997, pp. 212-217), West (2002), Tribulato (2010, p. 393), and Hackstein (2010, p. 402).

${ }^{4}$ All dates are $\mathrm{BCE}$, unless stated otherwise.

${ }^{5}$ Bacchylides' dialect, for instance, has fewer Aeolisms and more Ionicisms than Pindar's, see Jebb (1905, pp. 79-81), Colvin (2014, p. 148).

${ }^{6}$ For example, an elegiac couplet inscribed in Doric (131 CEG; Simonides, epigram 14 Sider) is found in a later source in Ionic (Plutarch, On the Malice of Herodotus 870e), see Nagy (1990, p. 53, n. 6). Moreover, Alcman's texts present later Laconian traits, that could not be present in the original songs; see Mitchell (1984, p. 20), Hinge (2006, pp. 3-5), Carey (2011, pp. 439-440), and Colvin (2014, p. 148). There is also some evidence of non-Ionian hexameters (such as Alcm. fr. 26 PMGF, and Sappho frr. 104-106 Voigt), but that could also be the result of a later Doricization or Aeolicization of the texts. The most important testimonies of Ionic metre in other dialects are archaic verse inscriptions, such as the Doric hexameters on Mantiklos Apollo (326 CEG), and the Doric elegiac couplets on the $6^{\text {th }}$ Century Ambracian monument (41.540A, 44.463 SEG). However, one should notice that Doricisms in Tyrtaeus and Theognis, for instance, are rare which might suggest that the poets at least avoided forms that were completely irreconcilable with the Ionic prototypes of the genre; see Horrocks (2010, p. 49). D'Alessio (2009a, p. 123) notes that even hexametric inscriptions in other dialects have a deep structure "easily 'translatable' into a relatively late stage of the ionicised epic diction".
} 
deeply non-Aeolic language of the Boeotian Hesiodic poems ${ }^{7}$. Furthermore, the Doric basis of the language adopted by the Aeolian Pindar and the Ionian Simonides and Bacchylides is undeniable. In summary, as they were being produced in different areas, some genres retained various elements which tied them to their geographical origins: metre, conventions, language ${ }^{8}$.

Not all Greek poetry shared the same fate as the more prestigious genres. While song was an omnipresent practice in Archaic and Classical Greece ${ }^{9}$, and its different manifestations shared themes, metres, and techniques, few traditions became as widely known and incorporated by other communities as Ionian elegy and épos or Dorian mélos. Local practices could have a degree of exchange with more prestigious traditions; however, this epichoric traditions appear to have exerted less direct impact on other regions.

Nonetheless, a strict Pan-Hellenic/epichoric opposition would be misleading. Some genres might have been restricted to their communities, while others might have circulated in nearby areas. The situation presents a full spectrum of possibilities. Even widely practiced genres must have expanded gradually from smaller areas to the whole of the Greek world. A case taken from better documented times, Attic drama, illustrates this process. From a local, if not isolated, phenomenon it became a general practice, to the point of being imitated by non-Greek peoples, such as Oscans and Latins. In Archaic times, an intermediary section of the spectrum consisted of traditions which, while becoming famous and producing Pan-Hellenic canonical poets, whose works were constantly reperformed, did not export their genres so widely. This was the case of Lesbian and Ionian mélos. Three of the canonical Nine Lyric Poets arose from these traditions: Sappho, Alcaeus, and Anacreon. Their early fame is attested by their depictions in Attic pottery and comedies. They had a strong influence on Greek poetic culture, integrating, for instance, the Attic sympotic imaginary in the classical period, with a considerable impact on local drinking songs ${ }^{10}$. Still, if the extant poetic corpus is

\footnotetext{
${ }^{7}$ Its more conspicuous trait being the rarer use of hiatus originating from lost digamma, which was still pronounced in Boeotian. On Hesiod's predominantly Ionic dialect, see West (1966, pp.79-91), Nagy (1990, p. 77, n. 123), Cassio (2009).

${ }^{8}$ On dialect in early Greek poetry, see D’Alessio (2009a, pp. 120-128), Silk (2009 and 2010), Tribulato (2010)

${ }^{9}$ On the role of song in archaic and classical Greek communities, see Herington (1985), Swift (2010, pp. 6-34), Hadjimichael (2019, pp. 23-57).

${ }^{10}$ For Anacreon's, Sappho's, and Alcaeus' reception in Attic symposia, see Yatromanolakis (2007) and Hadjimichael (2019, pp. 64-76). An extant Attic drinking song (fr. $891 P M G F$ ) is the only piece of archaic
} 
representative of archaic and classical realities, the genres of those poets, with their dialects and typical metres, were not so widely imitated as epic and elegy.

In the following pages, I present the unique position of one of those traditions: Aeolic song. In the first part, I briefly summarize what we know about its contact with other Greek poetry. I start with the ancient reception of Lesbian poetry and language, focusing on how classical Attic writers and later rhetors show both admiration for these poets and disapproval of their dialect. I also comment on Lesbian dialect, metre, and poetic tópoi. In the second part, I explore in more detail a much less debated aspect: Aeolic formulaic systems. In both sections, I show how Lesbian poetry tends to exhibit a pattern of connection to and independence from other Hellenic traditions ${ }^{11}$. I conclude with an account for this singular status of Aeolic song, based in the island's geopolitics, which framed the songs' performance, composition, and reception inside and outside Lesbos.

\section{Aeolic Poetic Tradition: Lesbos and Beyond}

There is little room for conjecture on how the songs of Sappho and Alcaeus were composed, performed, and reperformed in Mytilene, Lesbos and in the rest of the archaic Mediterranean. Almost no contemporary evidence on the reception and circulation of Lesbian poetry survives. There are no sixth-century inscriptions on the island documenting their religious and poetical practices. We first hear about the Aeolic poets in the 5th C. in Herodotus (2.134-135; 5.94-95), and all extant contemporary information comes from the poems themselves, which, in their fragmentary state, are not particularly helpful. Numerous lines or half-lines have little or no context, and even well-preserved songs are somewhat obscure. Since there often is no other comparable example within the corpus, it is difficult to interpret an individual song's meaning and social function. If the books of the Alexandrian edition of Sappho and Alcaeus had survived in a better state, it would be possible to discern generic and topical recurrences and compare them with surviving non-Lesbian texts, such as Homer, Pindar and Theognis. If, for instance, all

and classical evidence of an Alcaic imitation outside Lesbos (Alc. 249.6-9 Voigt). Atticized quotations in Aristophanes (Wasps 1234-5; Birds 1410) might also have originated from such songs; see Rösler (1980, pp. 91-106). Anacreon also influenced some of Bacchylides' banquet songs both metrically and thematically (frr. 17, 19, 20a Maehler); see D’Alessio (2016).

${ }^{11}$ The topics of part 1 and 2 have previously been discussed in my doctoral thesis (Andrade, 2019, pp. 16$74)$. 
Sappho's and Alcaeus' poems composed in glyconics with double dactylic expansion were extant, it would be possible to discern if the epic-sounding fr. 44 Voigt was an exception or an instance of a Lesbian subgenre. That would help to ascertain the relationship of that poem with Ionic epic. All in all, in its remaining condition, Lesbian poetry and its place in the archaic Greek world is and will remain an unsolvable riddle in many respects.

However, if the extant fragments and the testimonia do not give us a clear picture, it still provides valuable information. We know a lot about the metre, language, and style of Sappho and Alcaeus, and, despite the various biases influencing the later appraisal of the Lesbian poets, many authors had a more privileged access to their corpus than we do. Based on their evidence, we can get a more precise (even if blurry and kaleidoscopic) image of Aeolic lyric ${ }^{12}$.

An ancient proverb meaning "in the second place" was "after the Lesbian singer" (Hesychius $\mu .1004$ Latte) $^{13}$. A fragment of Sappho herself refers to a similar idea: "superior, as the Lesbian singer to the others" (fr. 106 Voigt) ${ }^{14}$. This reputation adds to the legendary or semi-legendary status of the poets in the island. According to Phanocles (fr. 1.11-22 Powell), after Orpheus' death, the streams brought his head and lyre to Lesbos, where the islanders gave him the proper funeral rites. That was the aítion for the prestigious Lesbian song tradition. The island was also home to Terpander and Arion, who were illustrious all throughout Greece and credited with important musical inventions (the former with the seven-stringed lyre, and the structuring of the nómos; the other with the development of dithyramb) ${ }^{15}$. Finally, two of its poets would form the Lyric canon and one of them, Sappho, would be called the Tenth Muse by the Hellenistic age. According to these testimonia, Lesbian music was an influential and cosmopolitan tradition, whose importance is hard to overestimate. This influence seems to have been recognized already in the $7^{\text {th }} \mathrm{C}$., when Archilochus, an Ionian, affirmed his ability to perform the Lesbian paián (fr. $121 I E G)^{16}$.

\footnotetext{
12 On the origins of Lesbian poetry, see Hooker (1977, pp. 56-83), Bowie (1981, pp. 49-60), and, more briefly, Liberman (2002, pp. xi-xiv). The following account is mainly based on their studies.

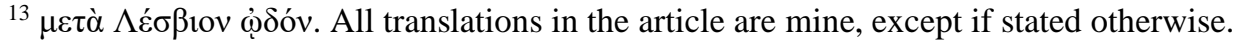

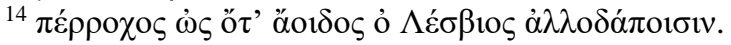

15 On Terpander's contributions to Greek music, see Pindar, fr. 125 Snell-Maehler, quoted in Athenaeus 14.635def; Suda $\tau 354$ (iv.527 Adler); the Parian Marble 34 Jacoby; Plutarch, On Music 3.1132c; 4. 1132de; 9. 1134b; 5.1132f; 12. 1135c; 28. 1140f.; 30.1141c; Pollux 4.66 (i.221 Bethe). On Arion, see Hdt. 1.23-24 and Suda a 3886 (i.351) Adler. On Lesbian kitharōidoí see Beecroft (2008) and Power (2010).

${ }^{16}$ On this fragment, see Swift (2019, p. 306-7).
} 
However, according to other sources, this might not be the whole picture. Even though Sappho and Alcaeus remained important poetic models through Classical and Hellenistic times ${ }^{17}$, some readers felt certain uncouthness in their language, which made them not wholly suitable models. Demetrius of Laconia $\left(2^{\text {nd }} C\right.$.) points to the obscurity of Sappho's and Alcaeus' Greek (On Poems 13 col. LXI-LXII, p. 123-124 Romeo). One century later, Dionysius of Halicarnassus, despite praising Alcaeus highly, berates the lack of clarity of his dialect (On Imitation 2.8, p.33 Aujac). Didymus $\left(1^{\text {st }} \mathrm{C}\right.$. BCE and $1^{\text {st }}$ C. CE), quoted in a scholion to Aristophanes' Thesmophoriazusae (162, p. 265 Dübner), also affirms that the dialect must have hindered the circulation of Alcaeus' songs. Finally, Apuleius $\left(2^{\text {nd }}\right.$ C. CE) mentions Sappho's sweetness as a counterpoint to the strangeness of her language (Apology 9). While Doric and Ionic verse diverged largely from Attic prose (the standard form of Greek for those Hellenistic and Imperial authors), and some varieties were considered harsh or unpoetic, neither were ever described as posing an unexpected difficulty to the reader ${ }^{18}$. For some reason, those Hellenistic and Imperial authors felt Aeolic to be especially remote from other Greek varieties.

An excerpt from Plato's Protagoras (341c) suggests that this perception might go further back in time. After Socrates' statement that, in the "Ode to Scopas" (fr. 542 $P M G F$ ), Simonides criticizes a saying by Pittacus, Prodicus suggests that the Mytilenean could not distinguish well between words because of his Lesbian origin and because he had been "nurtured in a barbarian language"19. While the last expression could be an allusion to Pittacus' Thracian father, Hyrrhas (or Hyrrhadius), it is beyond doubt that, for Plato's readers, the Lesbian dialect could present some comprehension difficulties to its native speakers ${ }^{20}$. While we do not know whether this perception reflected archaic and non-Athenian reception of Lesbian song, it implies that in the Pan-Hellenic canon, Lesbian poetry, despite all its influence and diffusion, sounded rather foreign.

When we look at the texts themselves, we find a combination of connection to and difference from other archaic exemplars. Archaic poetry was firmly based on inherited

\footnotetext{
${ }^{17}$ On the reception and imitation of Sappho in Classical, Hellenistic and Imperial times, see De Vos (2014), Coo (2021), Hunter (2021), Morgan (2021), and Bowie (2021).

${ }^{18}$ Pausanias (3.15.2), for instance, considers Alcman's Laconian dialect to be ill-sounding. On atticism in Greek imperial literature, see Swain (1996, pp. 17-100) and Silk (2009). Hadjimichael (2019, pp. 213-253) studies how the Hellenistic reception of the lyric canon originates in Athens. On the reception of Homer in the atticizing Imperial period, see Kim (2010).

${ }^{19} \dot{\varepsilon} v \varphi \omega v \tilde{n} \beta \alpha \rho \beta \alpha ́ \rho \omega \tau \varepsilon \theta \rho \alpha \mu \mu \varepsilon ́ v o s$.

${ }^{20}$ On Pittacus' Thracian origins, see Diogenes Laertius (1.74). 
elements on various levels. Poetic tradition manifested itself in dialect, metre, tópoi, and phrasing. These patterns formed registers shared by poets and audience, linked to a special type of communication. Such recurrences, though not a fixed set of rules, were respected and replicated. Some of them became typical of some genres and remained so even when they were exported to other regions. Despite some smaller divergences, Hesiod and Homer share dialect, metre, and traditional phrasing. Similarly, Bacchylides, a Cean, and the Theban Pindar composed their epiníkia in the same dialect, metres, components, and structures - sometimes honouring the same individuals. Traditional units, however, distinguished not only genres, but also poetic speech in general. Dialectal mixture and archaisms were typical of Greek poetry. Its metres were also shared by multiple kinds of poems, as hexameters by epic, elegy, epodes and mélos.

The same applies to traditional themes and song patterns. Laments on old age are attested in epic, elegy, iambus and mélos, and a prayer could be found in its typical structure as both the speech of an epic hero and a whole song by a lyric poet ${ }^{21}$. Phraseology was also a shared element, with the epithets recurring in different genres. Zeus is Kronídēs in Homer, Solon, and Pindar ${ }^{22}$. Earth is mélaina in Hesiod, Sappho, and the Theognidea ${ }^{23}$. The way a genre managed traditional material tells us a lot about its specificities and connections to the rest of Greek poetry.

The Lesbian tradition demonstrates its concomitant connection and uniqueness in many of those respects. The presence of Aeolic forms both in Homer and Doric lyric points to the Lesbian singers' influence on Greek poetic dialects (Hooker, 1977, pp. 5683). Conversely, in Sappho and Alcaeus there are possible Ionic forms (both colloquial and poetic) which point to a kind of interdependence with that tradition (Bowie, 1981, pp. 136-137). Nonetheless, such foreign influxes are not so noticeable in the surviving fragments as they are in Doric lyric, for example. On the other hand, the dialect itself, in its phonology, morphology, and vocabulary, evidences the uniqueness described by later writers.

\footnotetext{
${ }^{21}$ Laments on old age: Iliad 4.312-325; Mimnermus frr. 1-6 IEG; Alcm, fr. 26 PMGF; Semonides fr. 1 $I E G$; Sapph. fr. 58 Voigt; Anacreon fr. 395 PMGF. Prayers: Il. 1.37-42; 5.115-120; Sapph. frr. 1; 2; 5; 17 Voigt; Theognidea 1-18; Anac. fr. 357 PMGF. On tópoi and genres crossing different kinds of poetry, see Cairns (2007).

${ }^{22}$ For example, Il. 2.111; Solon fr. 31.1 IEG; Pindar, Olympian Odes 8.43.

${ }^{23}$ For example, Hesiod, Theogony 69; Sapph. fr. 1.10 Voigt; Thgn. 878.
} 
Metre shows similar tendencies. Doric and Aeolic lyric share some cola, and Ionic hexameters might be related to them ${ }^{24}$. We also find Aeolic cola such as glyconics, pherecratians and metres such as asclepiadaeans and ionics in Anacreon and the Attic drinking songs. Even if those rhythms might be parallel developments from a common origin, they evidence a connection between traditions. Moreover, some statements by Pindar (Olympian 1.102, Pythian 2.69, Nemean 3.79) suggest that such cola were perceived as Aeolian by late-archaic poets (Nagy, 1990, p. 94). Some Lesbian fragments, on their turn, are composed in hexameters (Sapph. frr. 104-106 Voigt), others in a related rhythm with some Ionian prosodic features, such as epic and Attic correptions (Sapph. fr. 44.5, 8 Voigt). But, despite these signs, Aeolic metre has a prosody of its own, clearly conservative and refractory of innovations common in other traditions, such as resolution, contraction and correption (West, 1982, pp. 29-30, 34). Moreover, although Aeolic cola and verses have relatives beyond Lesbos, Sappho and Alcaeus compose poems in traditional forms almost exclusive to them until the Hellenistic times ${ }^{25}$. We find one extant classical example of Alcaics and Sapphics each outside Lesbos, but these exceptions rather stress the strictly Aeolic character of those forms. The former (fr. 891 $P M G F$ ) is an Attic version of a stanza which was part of a longer song by Alcaeus (fr. 249 Voigt), the latter (fr. $953 P M G F$ ) pretends to be a song composed by Sappho herself. If the rarity of extant non-Lesbian poems is representative of ancient practice, Aeolic metre was particularly secluded from other Greek tradition as well.

As for genres and tópoi, there are plenty of Pan-Hellenic correspondences in the Aeolic corpus. Like the other Greeks, Sappho and Alcaeus composed hymns, propemptiká, prosphōnētiká, love poems, sympotic songs, invectives ${ }^{26}$. One also recognizes many poetic themes found elsewhere in archaic poetry: the morbus amoris, the political allegory of the ship, the people-devouring ruler, the abandoned shield, Wertpriameln, among others ${ }^{27}$. Everyone reading the only complete Lesbian piece, Sappho's “Hymn to Aphrodite” (fr. 1 Voigt), can easily perceive how much Aeolian poets

\footnotetext{
${ }^{24}$ See note 3 above.

${ }^{25}$ On Lesbian metre, see West (1982, pp. 29-34), and Battezzato (2021, pp. 121-129).

${ }^{26}$ For instance, Sapph. frr. 1, 2, 17 (hymns); 31 (love poem); 94 (propemptikón); 55, 57 Voigt (invectives). Alc. frr. 34a, 45, 307, 308, 325 (hymns); 350 (prosphōnētikón); 332, 335, 338, 346, 347 (drinking songs); 70, 72 Liberman (invectives).

${ }^{27}$ For example, Sapph. frr. 16 (Wertpriamel); 31 Voigt (morbus amoris); Alc. frr. 6, 208 (the ship's allegory); 70, 129 (the people devouring ruler); 428 Liberman (the abandoned shield). 
had in common with their Ionian counterparts ${ }^{28}$. Still, it is hard to find something specifically Lesbian in those respects, for the scant remains of archaic poetry leave us a vague idea of the output of early elegiac, iambic, and melic poets. The closest we can get to a specifically Aeolian tradition are Sappho's female homoerotic poems - and their similarities with Alcman's partheneîa present a caveat $^{29}$.

Fragments tend to be more informative about phraseology. While a single-line remnant hardly reveals the poem's original content, it is not difficult to recognize in it an expression found in other Greek poems. The most complete account on the subject, Anne Broger's Das Epitheton bei Sappho und Alkaios [The Epithet in Sappho and Alcaeus] (1996) shows that, excepting some hápax legómena, most Aeolic epithets can be found in other Greek traditions, sometimes recurring in the same form, sometimes with metrical or semantic variations (pp. 304-309). Broger's conclusion about epithets could easily be extended to other kind of phrases: numerous expressions attested in other authors exist alongside some unparalleled ones ${ }^{30}$. Again, we are faced with a tradition in deep interchange with the rest of the Greek world. At the same time, the adjustment of traditional phrases to distinctive Lesbian metres indicates a kind of local adaptation of a general Greek phenomenon. Furthermore, the hápax legómena epithets and expressions might also suggest an exclusively Lesbian traditional diction.

Nevertheless, we cannot be certain that these unparalleled instances are particularly Lesbian. Their apparent isolation might be due to the fragmentary status of most archaic poetry. On the other hand, the corpus mostly makes it impossible to differentiate between traditional syntagmata and ad hoc creations. Only some epithets connected to the island's religious practices can have their traditional local status confirmed (Broger, 1996, p. 307). Thus, the comparison between Lesbian and other Greek poetic diction suggests contact. Still, while we notice that Aeolic poets adapted this general Greek phrasing to their contextual or metrical needs, the comparison does not allow us to presuppose a distinctive Lesbian diction, but a distinctive Lesbian appropriation of a general tradition ${ }^{31}$. However,

\footnotetext{
${ }^{28}$ On the Aeolic connection to general Greek poetic tradition, see Rissman (1983), Meyerhoff (1984), Garner (2011b), and Kelly (2021).

${ }^{29}$ See Alcm. frr. 1.64-77, 3.61-63, 79-81 PMGF; Calame (1997, p. 244-258)

${ }^{30}$ Some of these parallels are listed in the next section.

${ }^{31}$ Nagy (1974, pp. 118-139) comments on the relationship between Aeolic metre and the epic-like formulae in Sapph. fr. 44 Voigt. For a different view of the same subject, see Ferrari (1986).
} 
one aspect of the Lesbian corpus can provide more information on its particular use of traditional phrasing: formulae.

\section{Lesbian Formulae}

Few themes have been so often debated and resulted in such little consensus as the concept of poetic formula. As widely known, the formula is the foundational concept of oralist studies of Greek epic, and the theme of Milman Parry's dissertation on Homer. For Parry, formulae are: "a group of words which is regularly employed under the same metrical conditions to express a given essential idea" (Parry \& Parry, 1971, p. 272). Initially, Parry saw in them the mark of a strong traditional diction, that predated the Homeric poems and informed them. He would later link it to the likely oral composition of those poems ${ }^{32}$. The definition of formula has expanded widely since, with some scholars focusing on analogous structures, others on lexical recurrence and some even proposing that Homer as whole is the result of formulaic composition ${ }^{33}$. Besides the expansion of the model, doubts have arisen concerning the validity of the definitions, the extent of epic formularity and its impact on composition and reception ${ }^{34}$. Nevertheless, few would today deny that hexametric poetry presents some kinds of formulae, encompassing both Parry's strict definition and more flexible kinds of repetition.

Formula studies have remained an almost exclusive territory of hexametric epic. In elegy, iambus, and lyric, the topic has been relatively neglected ${ }^{35}$. The cause of such scarcity appears to be the limitations inherent to formula studies, deeply affected by the different nature of the epic and lyric corpora. Formulae are patterns, and, consequently, their identification depends on repetition: labelling a phrase traditional is only possible if it recurs at least once in the poems. For instance, we know pótnia ("lady") is a typical epithet of Hera in epic because it recurs dozens of times (e.g. Il. 1.551, 568; 4.50; 8.198; Od. 4.513). On the contrary, there are some expressions that are repeated only once in the entire corpus. Kléos áphthiton ("immortal glory"), for instance, only appears in the extant

${ }^{32}$ After the 1929 article "The Distinctive Character of Enjambement in Homeric Verse" (Parry, 1971, pp. 251-265).

${ }^{33}$ Representative of a structural approach are Hoekstra (1965) and Janko (1982); lexical formulae were studied by Hainsworth (1967), Nagy (1974), and Sacks (1987). Finally, for formulae as the structuring principle of the whole epic poetry, see Nagler (1974).

${ }^{34}$ For a review of the debate, see Edwards (1986;1988), Russo (1997), and Kelly (2007, pp. 1-14).

${ }^{35}$ On elegiac formulae, see Giannini (1973) and Garner (2011a). On Sappho, see Nagy (1974, pp. 118139), Ferrari (1986), Garner (2011b). 
epic poems twice: in Il. 9.413 and in a Hesiodic fragment (fr. 41.5 Most). Had one of these examples been lost and were the phrase unattested in other genres (Sapph. fr. 44.4 Voigt; Ibycus $282.47 P M G F$ ), it would be impossible to know that this expression was traditional at all. Compared to what the original output must have been, the extant epic corpus is small. However, there are thousands of Homeric hexameters, not to mention the thousands of Hesiodic and hymnic lines, full of repetition. The situation in lyric, known mainly through fragments, is far more problematic. The state of the lyric corpus severely compromises the detection of traditional phrases, even if taken in the broadest senses. Furthermore, although lyric poets frequently use epic phraseology ${ }^{36}$, one cannot normally discern if they employ it systematically or just as a nod to hexametric poetry.

Nonetheless, that formulae might have played a role in non-epic genres is clearly shown in better preserved corpora, such as elegy and epinician poetry. Elegy exhibits recurring phraseology (Garner, 2011a). Pindar and Bacchylides present some formulaic material as well, albeit its different nature, which admits synonyms and is not attached to specific metrical contexts ${ }^{37}$. As for Lesbian poetry, even though their corpus is much smaller than the surviving works of Theognis and Pindar, its fragments are sufficiently numerous to reveal some patterns. Parry himself quotes Sappho and Alcaeus as examples of traditional, perhaps oral composition (Parry \& Parry, 1971, pp. 347-350). He laments the limitations imposed by the corpus, but argues that the dialect varieties in it, each with their own metric value, showed that "[th]e same forces which created the poetic epic language of Homer created the poetic lyric language of Sappho and Alcaeus", and that "their poetic language was drawn from an oral tradition" (p. 347) ${ }^{38}$. That is, since Sappho and Alcaeus, like Homer, used a poetic dialect whose mixed and traditional nature apparently served a metric purpose and enabled composition, probably the same could be said about their phraseology. If Parry only suggests the possibility, a few years later, Jesper Svenbro took the idea further. In a letter addressed to Albert Lord (Lord \& Lord,1995, pp. 63-64) he notes that some Lesbian lyricists' expressions recur in analogous metrical contexts, which we, by Parry's original definition, could indeed call

\footnotetext{
${ }^{36}$ See the example of kléos áphthiton above.

${ }^{37}$ Many of the recurrent themes and structures identified by Bundy (2006, first edition 1962) could be seen as flexible formulae, such as the phrasing related to storms and fair weather (pp. 47-50).

${ }^{38}$ See also Yatromanolakis (2007, pp. 197-210), and Garner (2011b).
} 
formulae. He offers three examples, all in Sapphic stanzas, which I list below, alongside similar passages from other Greek poetry:

\begin{tabular}{|c|c|}
\hline 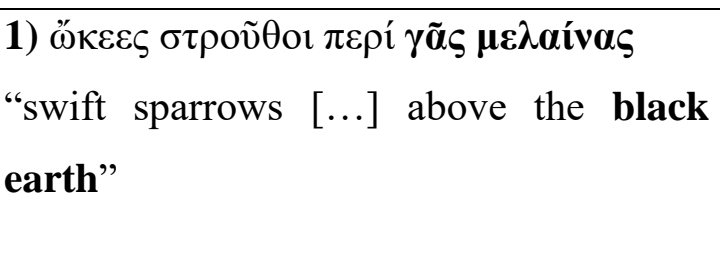 & Sapph. fr. 16.2 Voigt (str. Sapph.) \\
\hline 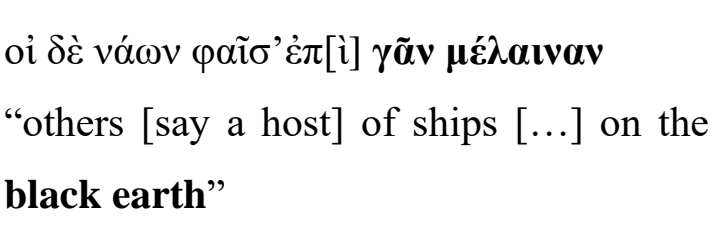 & \\
\hline $\begin{array}{l}\gamma] \tilde{\alpha} \varsigma \mu \varepsilon \lambda \alpha i ́ v \alpha \varsigma \\
\text { "black (earth?)" }\end{array}$ & Sapph. fr. 20.6 Voigt (str. Sapph.) \\
\hline 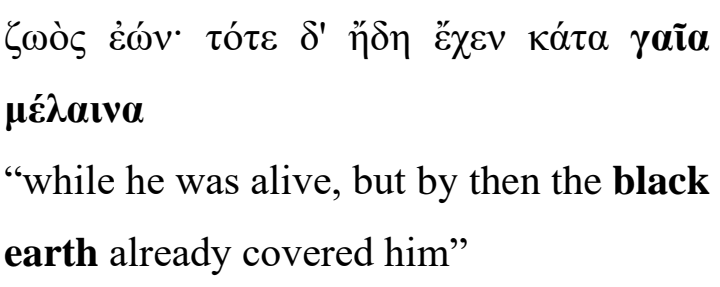 & Sol. fr. 36.5 IEG \\
\hline 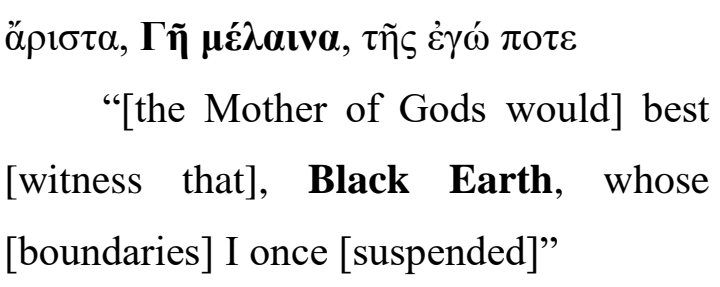 & \\
\hline 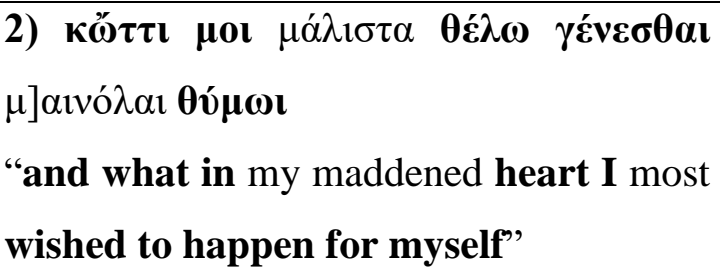 & Sapph. fr. 1.17-8 Voigt (str. Sapph.) \\
\hline 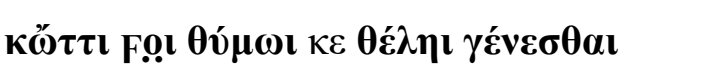 & Sapph. fr. 5.3 Voigt (str. Sapph.) \\
\hline
\end{tabular}

${ }^{39}$ Colon abbreviations are those by West (1982, pp. xi-xii). I follow the stanza abbreviations by Liberman (2002, p. cii). The metrical descriptions are based on those by Liberman (2002), for Alcaeus, and by Voigt (1971), for Sappho and the Alcaic fragments not included into Liberman's edition. Translations of the Aeolic texts are by David Campbell, with slight modifications, in order to stress formulaic similarities. In the case of Sappho's fr. 58 Voigt, I have included the new text found in P.Köln 21351 and 21376. Translations of other authors are mine. 


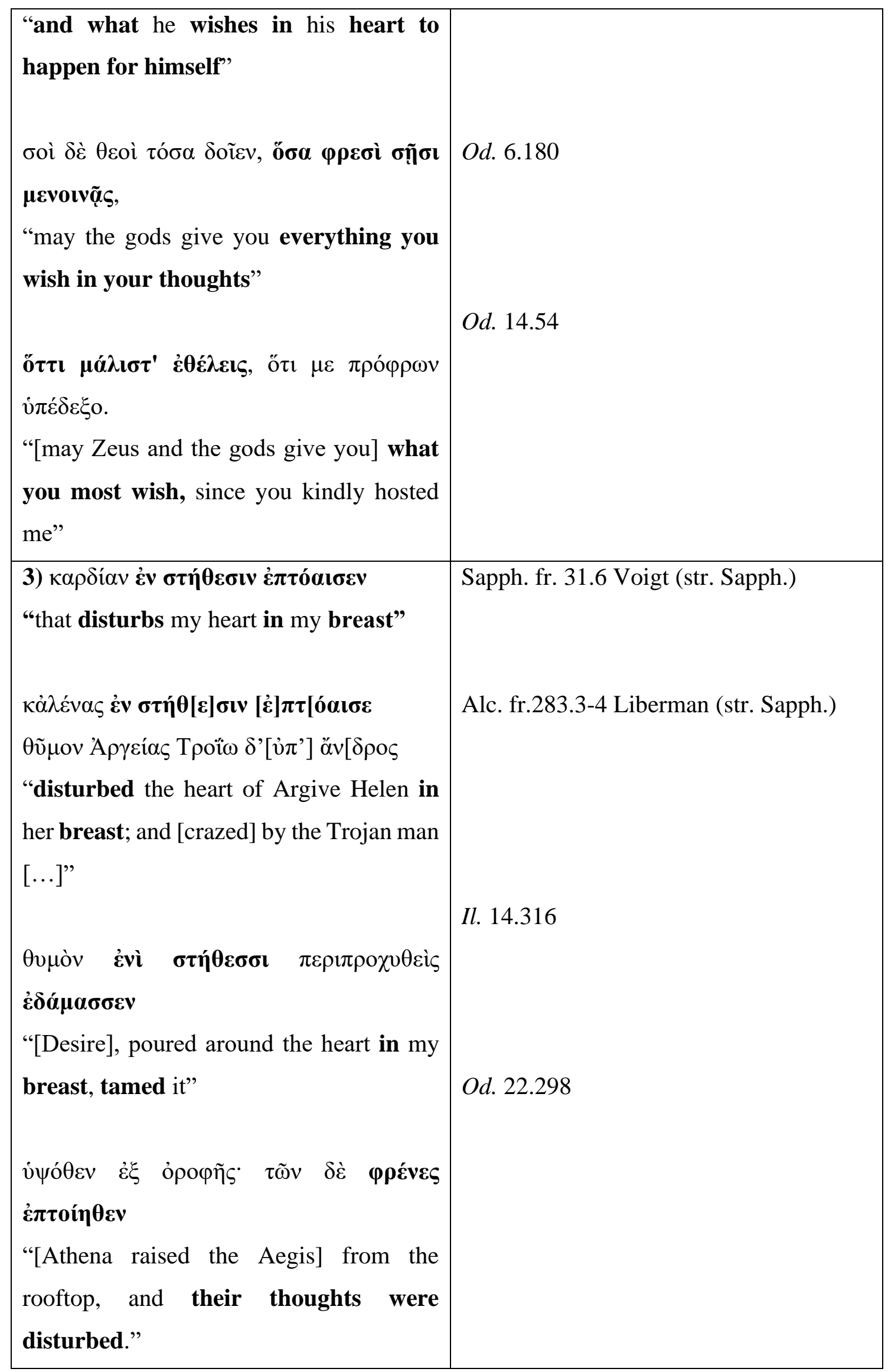

Table 1: Formulae in Sappho and Alcaeus found by Svenbro. 
Each of the three instances is "a group of words which is regularly employed under the same metrical conditions to express a given essential idea" (Parry \& Parry, 1971, p. 272), that is, it follows Parry's strict definition of formula. It appears, thus, that at least sometimes the Lesbians could be formulaic in that sense. But Svenbro's examples are not the only ones. Decades later, Yatromanolakis (2007, p. 203) found other instances in the Sapphic corpus. None of them fit the same stanza patterns, but all fill the same metrical sequence:

\begin{tabular}{|c|c|}
\hline 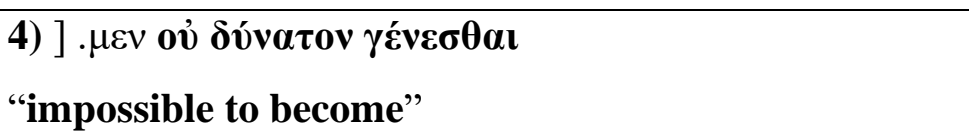 & Sapph. fr. 16.21 Voigt (str. Sapph.) \\
\hline 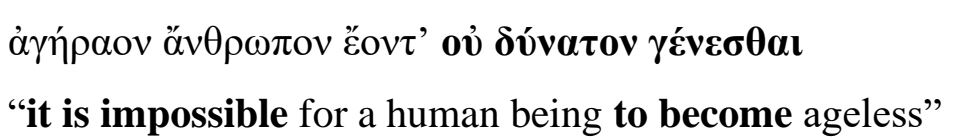 & Sapph. fr. 58.18 Voigt $\left(\right.$ hag $\left.^{2 \mathrm{c}}\right)$ \\
\hline 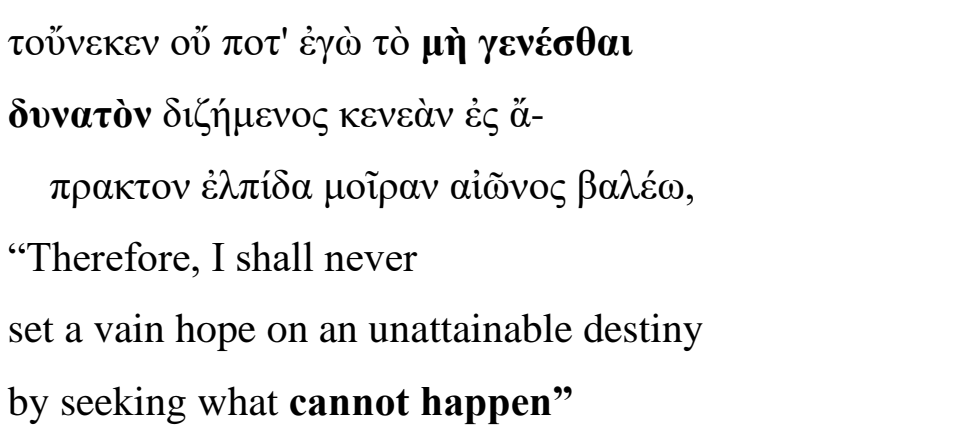 & Simon. fr. 542.21-3 PMGF \\
\hline 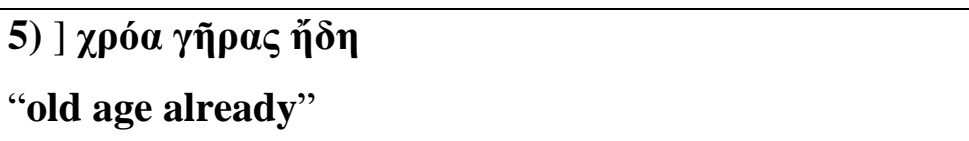 & Sapph. fr. 21.6 Voigt (str. Sapph.) \\
\hline 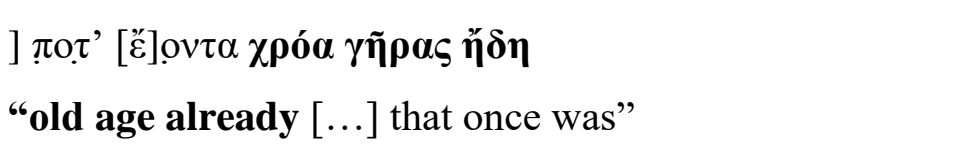 & Sapph. fr. 58.13 Voigt $\left(\right.$ hag $\left.^{2 \mathrm{c}}\right)$ \\
\hline 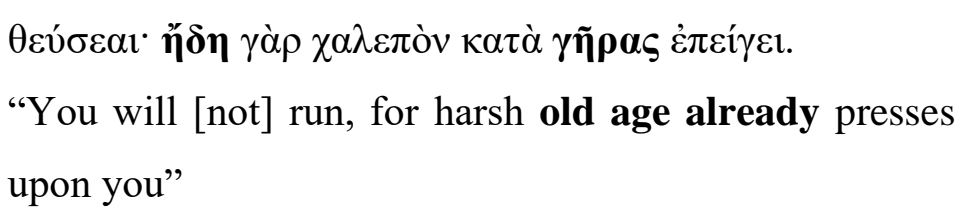 & Il. 23.623 \\
\hline 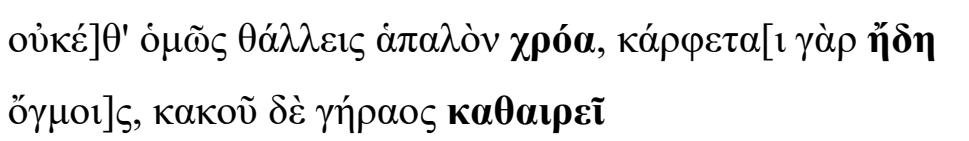 & Archil. fr. 188.1-2 IEG \\
\hline
\end{tabular}




\begin{tabular}{|c|c|}
\hline $\begin{array}{l}\text { "You are not blooming with your tender skin anymore, } \\
\text { as once you did, for it is already withering } \\
\text { in its furrows, and the }[\ldots] \text { of old age destroys it" }\end{array}$ & \\
\hline 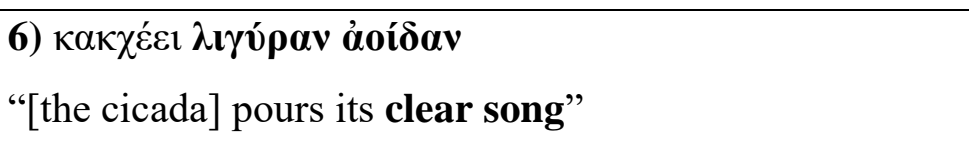 & $\begin{array}{l}\text { Sapph. fr. } 101 \text { A. } 2 \text { Voigt (metre } \\
\text { uncertain, perhaps gl } \| \text { hipp } \| \text { ) }\end{array}$ \\
\hline $\begin{array}{l}\text { ] } \sigma \alpha 01 \sigma \alpha \lambda \imath \gamma v ́ \rho \alpha v[\dot{\alpha} o i ́] \delta \alpha v \\
\text { "clear song" }\end{array}$ & $\begin{array}{l}\text { Sapph. fr. } 103.7 \text { Voigt (either } \operatorname{ar}^{2 \mathrm{c}} \text { or } \\
\operatorname{hag}^{2 \mathrm{c}} \text { ) }\end{array}$ \\
\hline 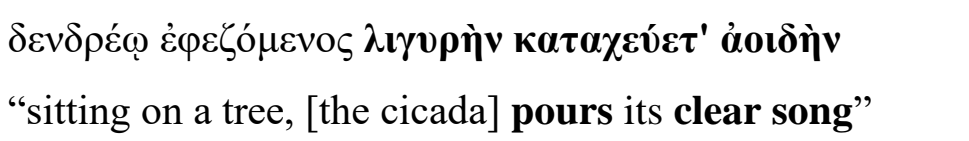 & Hesiod, Works and Days 583 \\
\hline 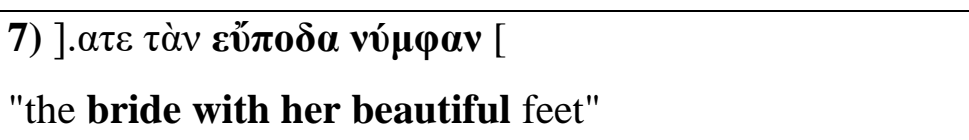 & Sapph. fr. 103.2 Voigt $\left(\mathrm{gl}^{2 \mathrm{c}}\right.$ or hag $\left.{ }^{2 \mathrm{c}}\right)$ \\
\hline 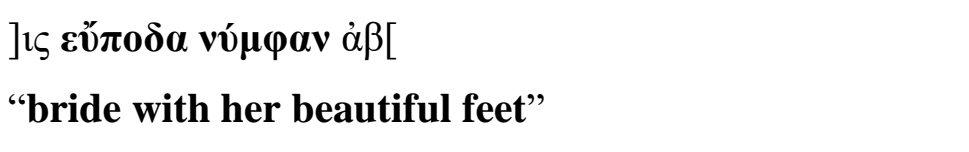 & $\begin{array}{l}\text { Sapph. fr. } 103 \quad \text { B. } 2 \text { Voigt } \\
(]-\_\cup \cup-\infty-[\text { uncertain })\end{array}$ \\
\hline 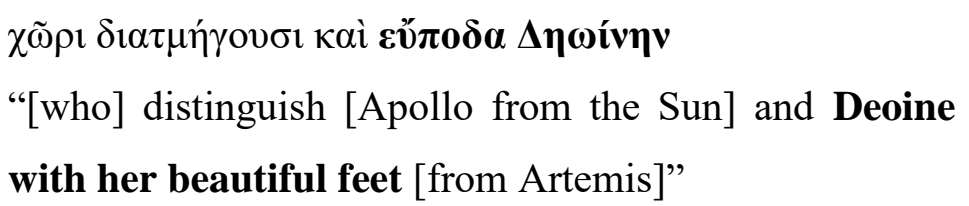 & Callimachus, Hecale 103.2 Hollis \\
\hline 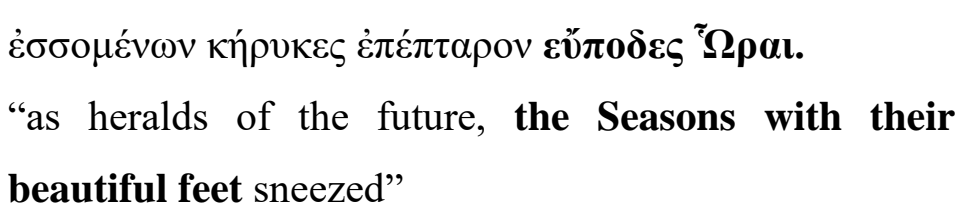 & Nonnos, Dionysiaca 7.107 \\
\hline 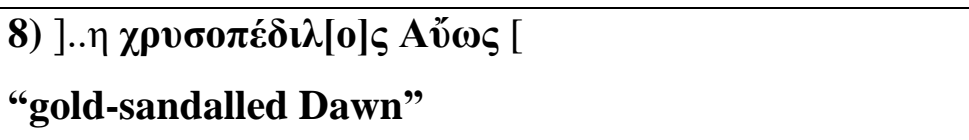 & Sapph. fr. 103.10 Voigt $\left(\mathrm{ar}^{2 \mathrm{c}}\right.$ or hag $\left.{ }^{2 \mathrm{c}}\right)$ \\
\hline 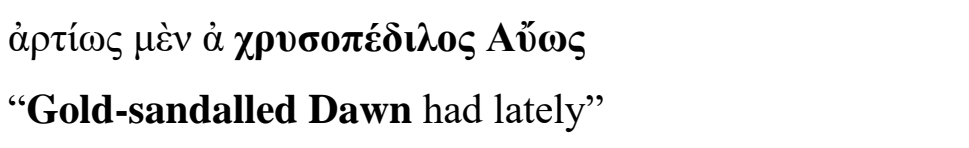 & Sapph. fr. 123 Voigt (cr hipp?) \\
\hline 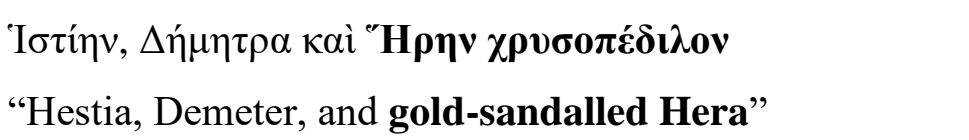 & Hesiod, Theogony 454 \\
\hline
\end{tabular}

Table 2: Formulae in Sappho and Alcaeus found by Yatromanolakis. 
To those examples we add other formulae found in both Lesbian poets ${ }^{40}$ :

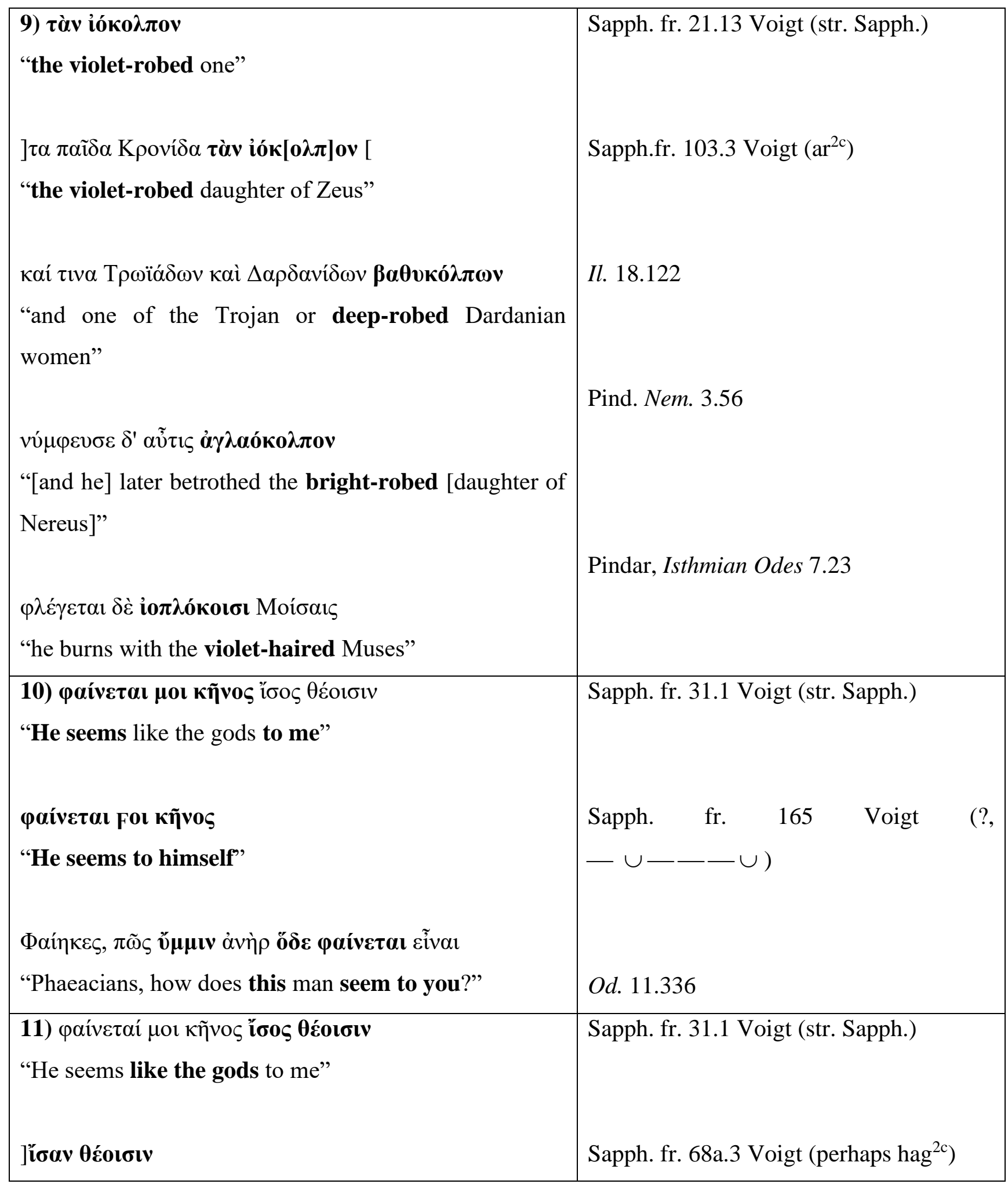

${ }^{40}$ A previous version of this survey can be found in Andrade (2019, pp. 26-35), including more flexible kinds of formulae. 


\begin{tabular}{|c|c|}
\hline 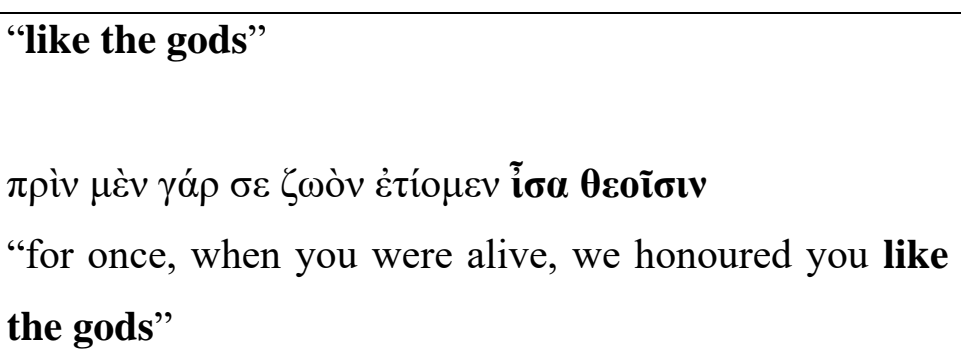 & Od. 11.484 \\
\hline 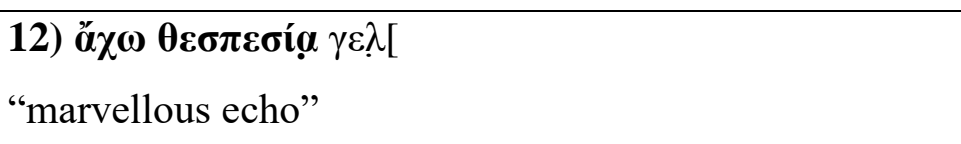 & Sapph. fr. 44.27 Voigt $\left(\mathrm{gl}^{2 \mathrm{~d}}\right)$ \\
\hline 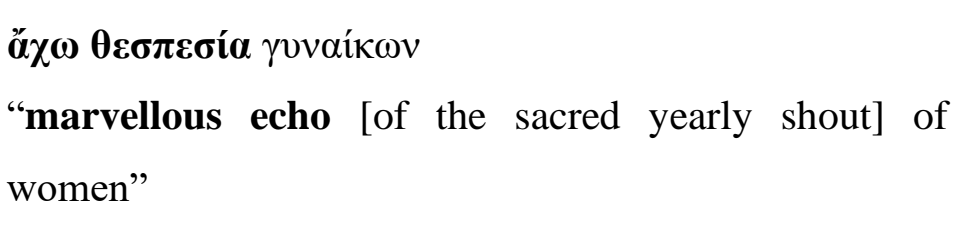 & $\begin{array}{l}\text { Alc. fr. 130b.19 Liberman }\left(\mathrm{gl}^{\mathrm{c}}\left\|\mathrm{gl} \mathrm{l}^{2 \mathrm{c}}\right\| \mathrm{gl}\right. \\
\left.\mathrm{gl}^{\mathrm{c}}\right)\end{array}$ \\
\hline 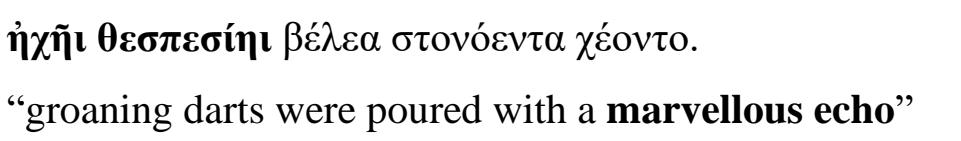 & Il. 8.159 \\
\hline 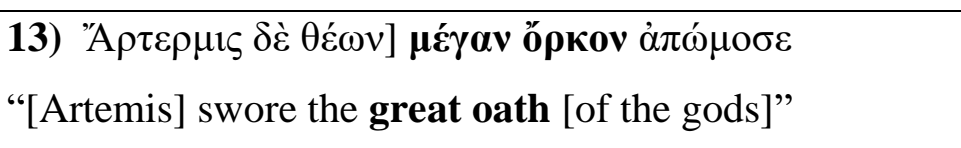 & Sapph. fr. 44A.4 Voigt (perhaps $\mathrm{gl}^{2 \mathrm{~d}}$ ) \\
\hline 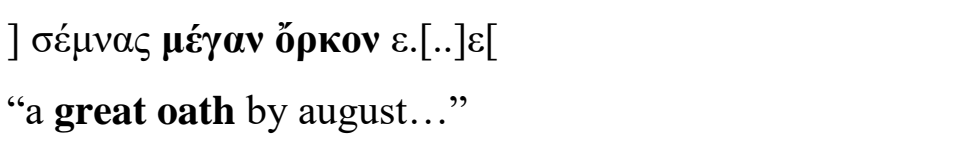 & $\begin{array}{l}\text { Alc. fr. 401N.11 Liberman (perhaps 2io } \\
\text { anacl } \| \text { ia dod) }\end{array}$ \\
\hline 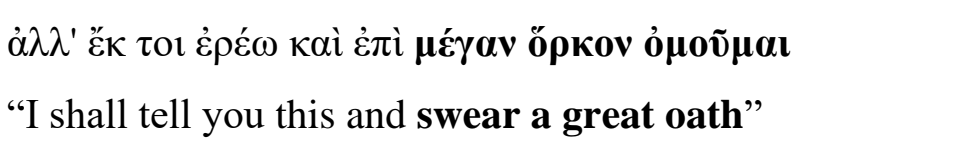 & Il. 1.233 \\
\hline 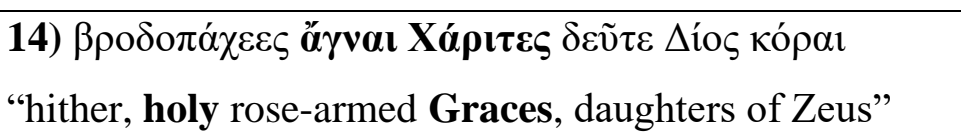 & Sapph. fr. 53.1 Voigt $\left(\mathrm{gl}^{2 \mathrm{c}}\right)$ \\
\hline 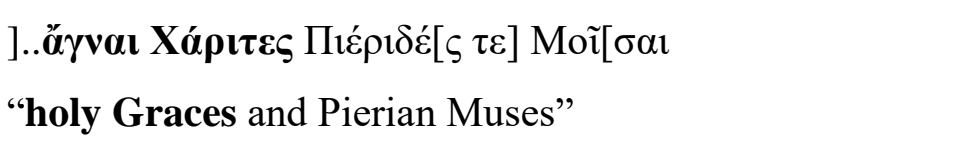 & Sapph.fr. 103.5 Voigt $\left(\mathrm{ar}^{2 \mathrm{c}}\right)$ \\
\hline 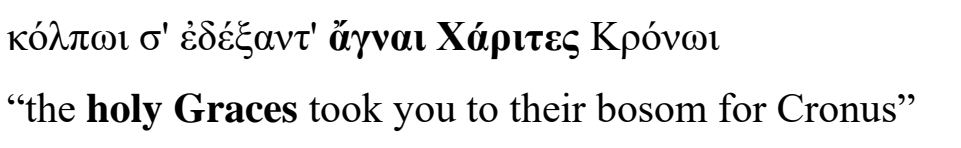 & Alc. fr. 386 Liberman (ia gl) \\
\hline 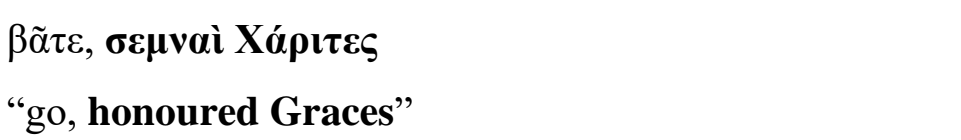 & Euripides, Helen 1341 \\
\hline
\end{tabular}




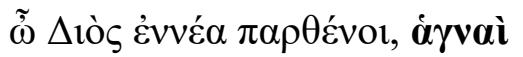

Aristophanes, Frogs 875-6

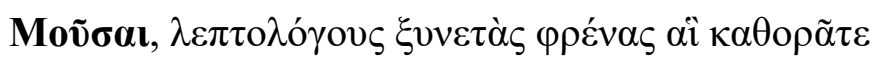

"O nine virgins of Zeus, holy

Muses, who behold subtly-speaking, smart thoughts"

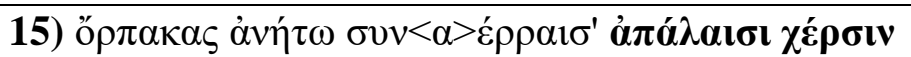
"binding together stems of anise with your soft hands"

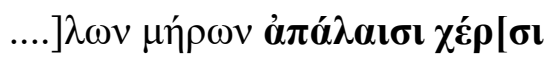

Alc. fr. 45.6 Liberman (str. Sapph.)

"their $[\ldots]$ thighs with soft hands"

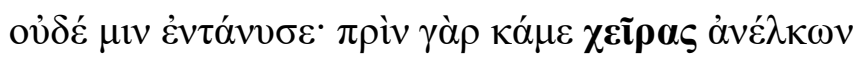

Od. $21.150-1$

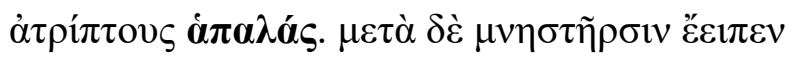

"But he did not string [the bow]. Before that, his unworn and soft hands were tired

of drawing it. And he said to the wooers"

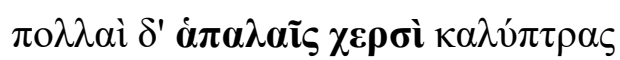

"[and] many women [tear] their veils with soft hands"

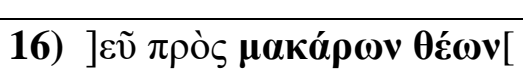

"at the hand of the blessed gods"

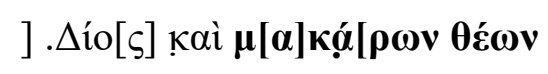

Alc. fr. $117 \mathrm{~b} .16 \quad$ Voigt (?,

"Zeus and the blessed gods"

]$\cup--\cup \cup-[\cup-)$

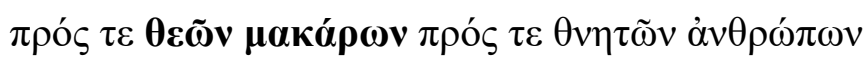

Il. 1.339

"by the blessed gods and by mortal men"

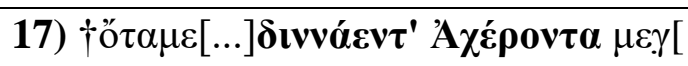

Alc. fr. 38A.2,8 Liberman (probably gl ${ }^{2 \mathrm{~d}}$ )

“eddying (?) Acheron"

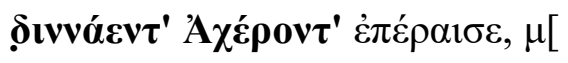

"he crossed eddying Acheron" 


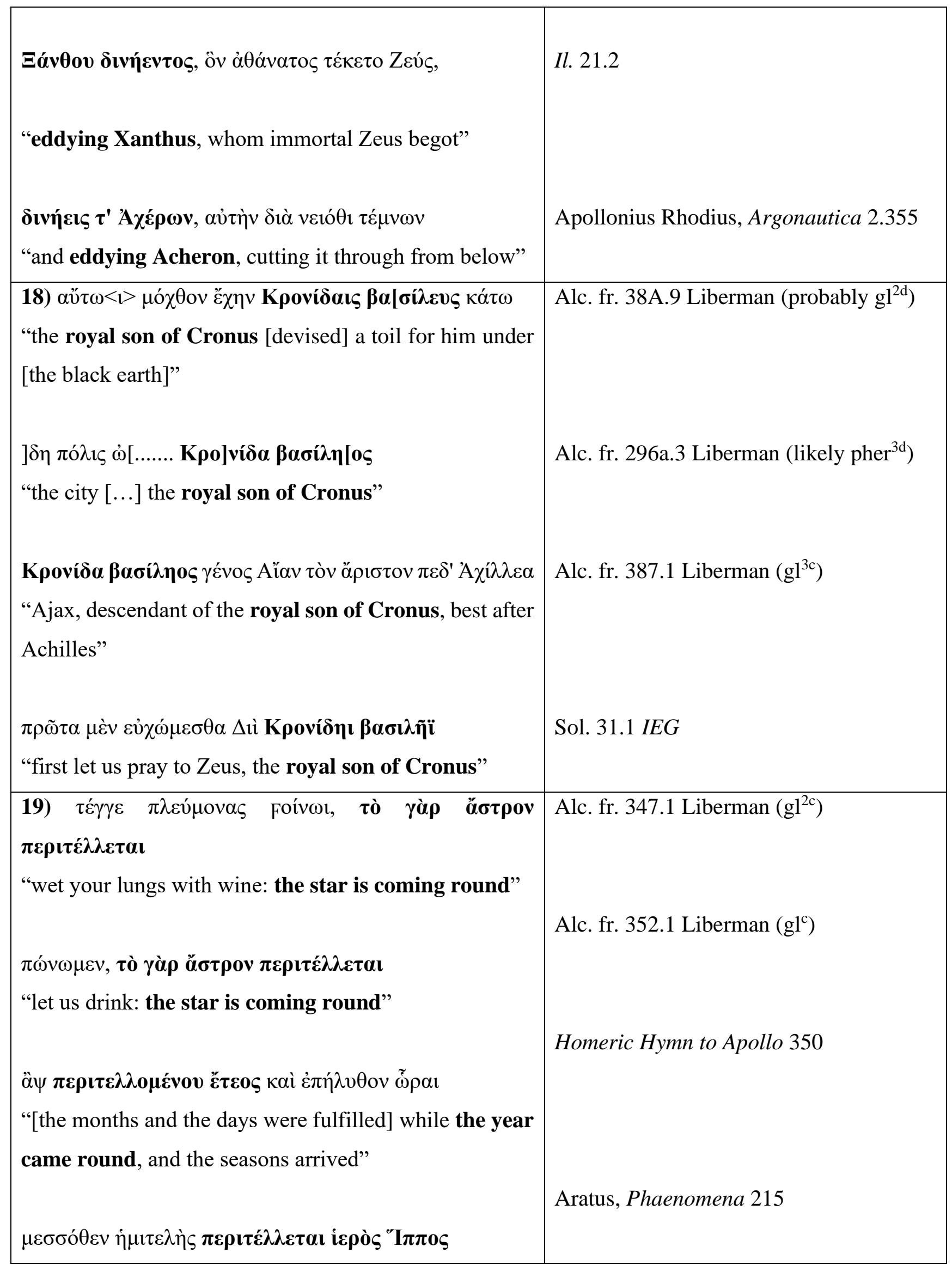


"half-complete from its middle, the sacred Horse comes round"

Table 3: Other formulae in Sappho and Alcaeus.

If we consider how scarce our Sapphic and Alcaic remnants are, it is surprising that we have been able to find nineteen strictly formulaic expressions, both in a semantic and in a metrical sense. These figures suggest that Parry's suspicions are right, evidencing a traditional, probably oral-derived diction in Sappho and Alcaeus. Like their Ionic relatives, Lesbian formulae tend to fill key portions of a verse ${ }^{41}$. Eight of them close hipponactean-derived verses $(1,3,4,5,6,8,11,15:[--\cup \cup]-\cup--)$, and two expanded glyconics (16 and 19: $[\cup \cup--] \cup \cup-\cup-$ ). Three open verses, both the Sapphic hendecasyllable $\left(10:-\cup-\_-\cup\right)$ and expanded glyconics (12 and 17: $-\ldots-\cup \cup-)$. One example fills both the beginning and the end of a verse (2: $-\cup-(\mathrm{X}-\cup) \cup-\cup-\longrightarrow)$. The remaining five expressions are more flexible, with different placement in the verse. All of them fill choriambs, a metrical sequence present in most Lesbian metres (7: $\cup \cup-\longrightarrow$; 9: $-\cup \cup-\mathrm{X} ; 13: \cup \cup-\cup ; 14$ : $\left.-\_\cup \cup-; 18: \cup \cup-\cup \cup-[-]\right)$. The small number of examples does not grant a deeper understanding of this Aeolic formulaic system. We cannot exactly know how they relate to cola, nor the exact laws governing the use of formulae. Semantically, most expressions have parallels in other Greek poetry. Some of them have the same metrical shape in other genres $(1,12,13,17,18)$; other contain the same words, but with phonological alterations $(1,11)$ or different order $(6,15)$. Nonetheless most are, in word choice and disposition, exclusively Aeolic: however related to Ionic tradition Lesbian phraseology might be, it forms a closed system of its own. This system, like dactylic diction, is likely the product of a long tradition. Thus, along with their distinctive cola, verses, and stanzas, Aeolic poets appear to have their own metrically conditioned inherited phraseology.

${ }^{41}$ On the position of formulae within the hexameter, see Foley (1993, pp. 121-167). Nagy (1974, pp. 118139), Ferrari (1986), and Garner (2011b) compare the metrics of traditional phrases in Sappho and their epic relatives. 


\section{Poetic tradition, performance, and the Lesbian experience of insularity}

In the politically and culturally fragmented archaic Greek world, a mixture of connection and isolation was the rule, either in the islands or the mainland cities. Local culture existed alongside intercultural contacts and exchanges. As we have seen, archaic and classical Greek poetry is a result of this contact, their different genres being tied to different regional and dialectal origins. For some genres originated in Ionia and the Peloponnese, connectedness resulted in them being adopted in other regions, with their characteristic metre and, sometimes, dialect. As for Lesbian poetry, there are numerous signs of its links with other Greek poetic practices as well. Nevertheless, it remained a mostly local phenomenon. If the intense traffic of the archaic Aegean explains the cultural and literary connection between Lesbos and the rest of the Greek world, would there be any geographical or cultural reasons for its relative isolation? A possible answer is Lesbos' experience of insularity, defined by two particularities: its size and its closeness to Anatolia. I shall discuss each of these in their possible impact on local poetic production.

Lesbos is the third largest island of the Aegean Sea, after Crete and Euboea, and harboured several communities. Despite their common Aeolian culture and language, the Lesbians formed six independent póleis: Mytilene, Methymna, Eresos, Pyrrha, Antissa and Arisba. Such variety in a well-defined insular territory caused a tension between unity and diversity, which could be felt in later, better documented times. First, during the Peloponnesian War, Methymna called on Athens to hinder a Mytilenian attempt of synoecizing the island under its command (Thucydides 3.2). Then, in the $3^{\text {rd }} \mathrm{C}$., the Lesbians established their koinón, whose agreement regulated the cooperation between the cities, which, nonetheless, formed no political unity (Ellis-Evans, 2019, pp. 199-247). In both cases, distinct in time and political context as they are, we can discern both a tendency and a resistance to unity.

This ambiguity seems to have existed in archaic Lesbos as well. On the one hand, the simple lack of political unity, archaeological remains of border fortifications, attested rivalries between cities, and at least one war demonstrates Lesbos' non-unitary culture ${ }^{42}$.

\footnotetext{
42 On border fortifications in northern Lesbos, see Mason (1993, p. 230). Hdt. 1.151 mentions the
} enslavement of Arisba by Methymna. 
Moreover, Lesbian contentiousness was proverbial in Antiquity ${ }^{43}$. On the other, there can be felt a sense of a Pan-Lesbian unity in the Archaic era. It was a general Greek attitude to consider islands as a unity that superseded the individual póleis ${ }^{44}$. In the case of Lesbos, there are many signs that show that both islanders and outsiders considered it to be an ethnic whole. Homer talks about Lesbos as a single, cohesive place, and alludes to Macar, the mythical king of the entire island ${ }^{45}$. In some extant fragments, Alcaeus and Sappho speak of the Lesbians as an ethnic unity ${ }^{46}$. Furthermore, there have been found archaic coins of individual cities bearing the inscription les, which points to an insular identity ${ }^{47}$.

There were also strong religious ties among all the cities on the island. Somewhere before the $7^{\text {th }} \mathrm{C}$., the archaic Lesbians founded a common sanctuary. Probably situated at Messon (modern Mesa, at the centre of the island), it was dedicated to the so-called Lesbian Triad: Zeus, Hera, and Dionysus ${ }^{48}$. Of the practices and rites attested, three concerned all Lesbian cities. The place appears to have received exiles and, in Hellenistic times, was the seat of a Pan-Lesbian alliance ${ }^{49}$. Moreover, and more importantly for our theme, one or more festivals were held at Messon, celebrated by all the cities on the island. Those practices could have had an influence on Lesbian poetry. In Hesychius ( $\mu 932$ Latte), we hear of a Pan-Lesbian festival called mesostrophôniai hèmérai, the name of which could be a reference to the sanctuary ${ }^{50}$. There is little information about this festival

\footnotetext{
43 Aelius Aristides (24.54-56) compares Rhodes' harmony to Lesbian contentiousness. On the differences between the two islands, see Mason (1993, p. 225) and Malkin (2011, pp. 65-95). On Lesbian rivalry, see also Ellis-Evans (2019, pp. 222-243).

44 Constantakopoulou (2005) collects and comments the evidence from the Classical and Hellenistic periods. Ellis-Evans (2019, pp. 222-243) shows how a sense of Lesbian unity did not exclude intense rivalry between the cities.

${ }^{45}$ Lesbos is described as single place in Il. 9.129, 271 and called "seat of Macar" (Mákaros hédos) in Il. 24.544. On the traditions about Macar, see Constantakopoulou (2005, pp. 6-7)

${ }^{46}$ Sapph. fr. 106 Voigt (on Lesbian singers); Alc. frr. 129.1 (on the Pan-Lesbian sanctuary), and 130b.17 Liberman (on the Lesbian women at the kallisteîa)

${ }^{47}$ Constantakopoulou (2005, p.11). For Ellis-Evans (2019, pp. 224-227), the coins were issued by Mytilene, in an attempt to lay claim to Lesbian identity.

48 A Pan-Lesbian sanctuary dedicated to the three deities is mentioned in Alc. fr. 129 Liberman and first connected with the temple at Messon, in which the Hellenistic Lesbian koinón was formed (according to a second-century inscription, IG XII Suppl. 136) by Robert (1960, pp. 300-311). See also Constantakopoulou (2005, pp. 15-16), Caciagli (2016), Nagy (2016, pp. 478-487), and Ellis-Evans (2019, pp. 227-230).

49 A scholion to Alc. fr. 114 Liberman says the poet and his allies were exiled in Pyrrha, which lies near Messon; see Robert (1960, p. 305), Liberman (2002 p. xix), Ellis-Evans (2019, p. 229). In fr. 130b Liberman, Alcaeus speaks of being exiled in a place where Lesbian women sing and take part in a beauty contest. On this festival, see below.

${ }^{50}$ See Robert (1960, pp. 303-304), Nagy (2016, p. 464, n. 29), and Ellis-Evans (2019, p. 227, n. 108). Bierl (2016, p. 324, n. 60) and Nagy (2016, pp. 463-464, 470-471) entertain the possibility that the name refers to the time of the year in which the festival was celebrated, translating it as "the days that turn at the middle" (maybe, Bierl suggests, the days after an equinox).
} 
in the sources, but, by taking other archaic local Greek festivals such as the Carnea and Panathenaea, it is possible to conjecture that poetic performances of different types took place during the celebrations. In addition, we hear of a female beauty contest at Lesbos, probably taking place at Messon, which might have been part of the festival mentioned by Hesychius ${ }^{51}$. According to Alcaeus' fr. 130b.18-20 Liberman, it included singing of some kind.

While we ignore the nature of these songs, there is some evidence for female choral performances at Messon. A fragment of a hymn to Hera by Sappho (fr. 17 Voigt) mentions the Triad and might have been composed for performance there ${ }^{52}$. Likewise, an anonymous epigram (Anth. Pal. 9.189) fictionalizes a chorus performance led by Sappho in a sanctuary of the goddess (Robert, 1960, p. 312, n.4). Thus, probably the Pan-Lesbian témenos hosted one or more kinds of poetic performance ${ }^{53}$. If this hypothesis is true, these festivals would be a perfect occasion for poets to display their abilities. There, they would be able to face a larger audience, interact and vie with their peers, and get acquainted with new songs and poetic techniques. Furthermore, if the festivals took place in spring or summer, the sanctuary's proximity to the sea makes the attendance of non-Lesbian guests probable ${ }^{54}$.

Like archaic Sparta and archaic and classical Athens, Lesbian cities formed prosperous, populous, and powerful polities. Mytilene in special was a major naval power in the Aegean at the turn of the $7^{\text {th }}$ to the $6^{\text {th }} \mathrm{Cc}$., with territories and client cities in Aeolis and in the Troad (Mason, 1993, pp. 226-231). Its power would attract seafarers from the whole Mediterranean world, for commercial and other purposes, not to mention religion, which had a major role in the sea traffic in the Aegean world ${ }^{55}$. If non-Lesbian attendance was expected, the festivals would also provide a chance for poets to become known

\footnotetext{
51 The contest is mentioned in Alc. fr. 130b.13-20 Liberman (linked to the place of his exile) and in Theophrastus fr. 564 Fortenbaugh (quoted in Athenaeus 13.610a-b), with no open mention to its exact location. In a scholion to Il. 9.128, it is located in a Lesbian temple of Hera (which was one of the deities worshipped at the témenos). See Robert (1960, pp. 312-315).

52 Robert (1960, p. 314), Caciagli (2016, pp. 425-426), Nagy (2016, pp. 478-481). For a more nuanced view on the relationship between this poem and ritual performance, see D'Alessio (2018, pp. 42-45) and Power (2019, pp. 93-101).

${ }^{53}$ On Messon as a possible stage for poetic performances in Lesbos, see Caciagli (2016) and Nagy (2007 and 2016). On poetic singing at the kallisteîa, see Nagy (2007, p. 215; 2016) and Boterf (2012, pp.135142).

${ }^{54}$ If the name of the messostrophôniai hèmérai refers to an equinox, that could be the spring equinox.

${ }^{55}$ On the role of religion in the Aegean traffic, see Constantakopoulou (2007, pp. 29-60) and Rutherford (2013).
} 
beyond the Aeolian cities of the Eastern Aegean. The evidence does not make room for much speculation, but, if these festivals really included poetic contests, they would be a major incentive to Lesbos' flourishing poetic activity. Its Lesbian character would encourage the use of the local dialect, metres, and traditional phrasing, and a Pan-Lesbian contest would entice its many aoidoí to compete against each other, perfecting their techniques in the local traditional genres. Furthermore, the likely non-Lesbian attendance would offer an opportunity of fame outside the island - and would partly explain the reputation of non-travelling Lesbian poets in the Greek world ${ }^{56}$.

A parallel with this epichoric poetic festival, stimulating the cultivation and development of local poetic forms by means of regional competition, was the Great Dionysia and Lenaea in Athens. As Athenian affluence in the $5^{\text {th }} \mathrm{C}$. warranted the financing of local poets and their fame throughout the Greek world, the prominence of Lesbos in the $7^{\text {th }}$ and $6^{\text {th }} \mathrm{Cc}$. could have bolstered the poetic performances and fame of its aoidoí within and outside the island. In summary, the first aspect of Lesbos' insularity which would have affected its poetry was the concomitant unity and variety of its territory and culture, a tension that would foster the development of traditional local forms.

Another aspect of Lesbian insular geography was its closeness to Anatolia. No other Aegean island lies so near Asia Minor, being at the closest only $10 \mathrm{~km}$ apart (Ellis-Evans, 2019 , p. 157). That position stimulated from early on contacts with the mainland, which remained somehow in Greek collective memory. In Homer, for instance, Lesbos is part of Priam's empire and is sacked by the Achaeans ${ }^{57}$. In addition, like Troy, who had allies in Thrace, Mytilene seems to have had a strong connection to that region as well. Not only the Mytilenean settlement of Ainos was founded there, but also Pittacus, the son of a Thracian father, rose to pre-eminence and power in the city. Lesbian poets, in their turn,

\footnotetext{
${ }^{56}$ Of course, there are other possible explanations, since e.g. foreign visitors taking part in local symposia could bring this repertoire home, and Lesbian guests could perform their native songs in other cities. On the symposium as a means of diffusion of Alcaeus' and Sappho's songs, see Rösler (1980, pp. 91-106) and Bowie (2016). In the case of Sappho, some girls of her entourage married into foreign families, and most probably brought some of her songs with them (see the discussion on fr. 96 Voigt below). Moreover, we should also not exclude the possibility of Alcaeus' songs becoming known outside Mytilene during his exile. On Alcaeus as a travelling poet, see Bowie (2009, pp. 118-122). Sappho might also have gone into exile, as mentioned in Mar. Par. 36 Jacoby.

${ }^{57} \mathrm{Il}$. 24.544 mentions the island as part of Priam's empire. The sack of Lesbos is mentioned in Il. 9.129, 271. 
openly valued their ties to Anatolia, mentioning Lydia as a place with which the Lesbians had strong commercial, martial, and matrimonial ties ${ }^{58}$.

Textual and archaeological sources concur here. Material remains from the Bronze Age reveal a place that was an integral part of the Anatolian world (Spencer, 1995). The name "Lesbos" is perhaps mentioned in Hittite sources (as Lazpas) and many of Lesbian toponyms seem to have arisen from non-Greek languages (p. 275, n. 24; p. 290, n. 133). These contacts did not cease after Bronze Age. Iron Age findings point to a continuing connection to Asia Minor (pp. 288-293). Furthermore, in the Archaic era, there was even a territorial and political tie: Lesbian colonies in the Troad and Aiolis, and the Mytilenean mainland settlements, the peraía ${ }^{59}$. Beyond territory, there were cultural connections to Anatolia as well. Greek settlements in or near Asia have many and well-known ties of every type with non-Greek populations, the best known of which is the adoption of Eastern cults, such as those of Aphrodite, Adonis, and Cybele. Lesbos, however, shared some cultural traits with Anatolian (and South-Eastern Thracian) peoples which set it apart from other Eastern Greek cities. Aside from the aforementioned marriages and military and commercial ties, there is a piece of evidence that points to a special connection between the Lesbians and Anatolia: its pottery. While some remains of Laconian, Corinthian, Attic, and East Greek painted ware were found in some sites, most archaic Lesbian vessels were greyware ${ }^{60}$. The high quality of the material suggests that it was prestigious, and it was in those vessels that the equally famous Lesbian products were sold overseas (Spencer, 1995, p. 301). In the archaic era, greyware was already an established tradition in Anatolia and Thrace (Pavúk, 2008), and the Lesbians' preference for it suggests that special connection to Asia mentioned in Homer, Sappho, and Alcaeus.

Therefore, if the insular geography contributed to Lesbos' cultural unity, while separating it from the rest of the world, at that same time, its proximity to the Asian continent, fomented a connection to other local cultures, which set it apart from other Eastern Greeks. The Aeolian settlers, while maintaining distinctively Greek customs

\footnotetext{
58 Sappho mentions a fine Lydian headband in fr. 98 Voigt and envisage a girl of her circle living as a married woman in Lydia in fr. 96 Voigt. Alc. fr. 69 Liberman refers to a military alliance with the Lydians. Another Asian alliance is mentioned in Alc. fr. 350 Liberman, where the poet salutes his brother, who fought as a mercenary on the side of the Babylonians. See Thomas (2021, pp. 30-33) on interpretation problems in this fragment.

${ }_{59}$ Mason (1993, pp. 226-231); Ellis-Evans (2019, pp. 155-197); Thomas (2021, pp. 27-28).

${ }^{60}$ On grey ware in Lesbos, see Cook (1997, pp. 34, 115-117), and Spencer (1995, pp. 301-303). On painted ware found in Mytilene, see Schaus (1992).
} 
(such as language, religion, poetry, and burial practices), appear to have adopted some of the previous, Anatolian-oriented culture and furthered those ties (Spencer, 1995, pp. 303305; Thomas, 2021, pp. 29-33). If that reflected in their pottery, that might also have had an import on festivals and poetic practices.

It is not possible to know how Lesbian poetry related to Iron Age Anatolian songs ${ }^{61}$, but as those connections had stimulated a distinctive pottery tradition, it could also lead to Lesbian song forming a world of its own. In fr. 96 Voigt, Sappho appears to envisage a musical performance of a member of her entourage in Lydia (Boterf, 2012, pp. 40-41). We cannot know the details of such a presentation, but that she could imagine a Greek song performed in Sardis points to the possibility that the poetries of both regions could have a connection, as their aristocratic families, economy and military power had. At least musically, testimonia associate Lesbian poets with Anatolia. Pindar says Terpander invented the bárbitos after listening to the paktís in a Lydian banquet (fr. 125 SnellMaehler). Furthermore, he and Sappho are said to have invented the Mixolydian harmonía ([Plut.] Mus. 16.1136c, 28.1140f). We cannot be certain of the truth value of those attributions and connections, but they are evidence of Lesbian musical ties to Asia Minor. If Sparta's greatest poet was perhaps a Lydian and said he learnt his songs from an Anatolian bird ${ }^{62}$, it seems likely that Lesbos, influenced by Lydia in so many aspects, would also have poetic ties to it.

In summary, Lesbos' geographical position might have contributed to the singular status of its poetry in at least two ways. At first, its size, territorial unity, and relative isolation, along with its ethnical and linguistic cohesion, formed a cultural and religious unity of multiple and prosperous communities. In the Pan-Lesbian sanctuary at Messon, the Lesbians likely held festivals and poetic competitions. That consolidated Lesbian

\footnotetext{
61 On the rare extant Lydian poetry see Littmann (1916, pp. 58-62) and West (1972). The most wellpreserved song does not, however, exhibit many affinities with Lesbian verse. On Phrygian metre, which might or not be directly related to Greek verse, see West (2003). It is worth remarking that both Phrygian and Lesbian metres display the archaic Indo-European anceps opening and similar cola (West, 2003, pp. 85-86). Nonetheless, it is impossible to know whether these phenomena were separate developments or stimulated each other somehow.

${ }^{62}$ As widely known, ancient testimonia disagree on Alcman's origin, with some pointing to Sparta, and the majority to Lydia: Anth. Pal. 7.19, 7.709; Velleius Paterculus 1.18.3; an epigram quoted in Schol. Pind. i.11 Drachmann; the Scholiast B on Alcman 1.58s. PMGF; the scholion on P.Oxy. 2389 fr.9 col. 15 ss. Others manifest doubt: in Anth. Pal. 7.18, and a biographical commentary on P.Oxy. 2506 fr. 1 col.ii. Two fragments by Alcman seem to allude to a Lydian origin. In fr. 16 PMGF he speaks of a wise man from Lydia, while in fr. $39 P M G F$ he claims to have learnt his song from chukar partridges, typical from Anatolia (Borthwick apud Arnott, 1977, p. 337, n.1).
} 
traditions, encouraging individual poets to excel, exchange, and develop their poetic techniques. Secondly, Lesbos' Anatolian connections, attested both in literature and material culture, suggest communities more closely related to non-Greek peoples. If this affected their crafts, like pottery, it most likely influenced music and poetry as well.

\section{Conclusion}

As demonstrated above, Lesbian poetry had a special position in archaic Greece. In the first two parts, I showed how archaic Lesbian song was perceived as an especially different kind of Greek poetry. From Plato to Apuleius authors point to the strangeness of the Lesbian language, which can be extended to several traits of its poetry. Lesbian song did not expand as widely as Ionian and Dorian traditions, being reperformed, but rarely composed outside its original setting. Two of its poets, however, achieved PanHellenic fame while composing in their own tradition. Lesbian poetry was both isolated and connected to the rest of Greek literature, in all its components. Its language is unique, but both influenced and was influenced by other dialects. Its favoured metres had a conservative prosody, which normally rejected Ionic-Doric innovations. Nevertheless, sometimes poets could use foreign metres and rhythmical traits. Lesbians also shared genres, tópoi, and traditional phrasing with other Greeks. Finally, the fragments show that not only the Aeolians adapted the Pan-Hellenic phrasing to their metres, but also developed a formula-system of their own.

In the last part, I demonstrated how this apparent paradox of isolation and connection to the Greek world could be partly explained by Lesbos' insular geography. Lesbos' territorial unity, aided by shared dialect and origins, consolidated a distinctive cultural cohesion. At the same time, the island was large and rich enough to hold six different póleis, which would both co-operate with and compete against each other. The common sanctuary at Messon embodied this tension between unity and rivalry of Lesbian cities, for it was a place to settle political differences and celebrate Pan-Lesbian festivals, which even included a beauty contest. It is very likely that festivals as this would also hold poetic competitions, as was normally the case throughout the Greek world. If this is true, these festivals would offer an opportunity for the poets to meet their peers, exchange songs and techniques, compete among themselves, and show their art before a larger audience. The explicitly Lesbian character of these festivals would promote the use of local forms, and the likely presence of non-Lesbian foreigners would ensure that the 
winner would gain fame across the Mediterranean. That could partly explain why Sappho and Alcaeus became so well-known, despite their specific forms hardly being imitated outside Lesbos before the Hellenistic era.

The other aspect of Lesbos' geography probably influencing its poetry is its proximity and connection to Anatolia. These ties are attested in diverse sources from the Bronze to the Iron Age: literary memory, myths, and political facts such as territorial occupation, colonization, and political, marital and commercial ties. Especially significant is the fact that at least in one respect the Lesbians remained more closely connected to Anatolia than to other Greek populations: in its pottery. Lesbos imported some painted ware, but preferred bucchero to them, a technique that was common among non-Greek North-East Aegean populations. That points to the possibility that Lesbian poetry as well might have entertained an Anatolian connection that set it apart from other Greek poetry. Few Iron Age Anatolian poems survived, and it is impossible to know how those traditions related to Lesbos. Nevertheless, one fragment of Sappho seems to envisage a musical performance of a Lesbian woman in Lydia. According to some sources, the Lesbians had musical ties to Anatolia as well. Such a connection must remain a hypothesis, but it seems probable and sustained by the limited evidence.

Article received in: 18/05/2021

Approved in: 17/06/2021 


\section{BIBLIOGRAPHIC REFERENCES}

Andrade, T. B. C. (2019). A referencialidade tradicional na poesia de Safo de Lesbos [Unpublished doctoral thesis]. Universidade de São Paulo. https://www.teses.usp.br/teses/disponiveis/8/8143/tde-08082019-112625/pt-

br.php

Arnott, W. G. (1977). Some Peripatetic Birds: Treecreepers, Partridges, Woodpeckers. Classical Quarterly 27 (2). (pp. 335-337).

Battezzato, L. (2021). Sappho's Metre and Music. In P. Finglass \& A. Kelly (Eds.) The Cambridge Companion to Sappho. Cambridge: Cambridge University Press. (pp. 119-134).

Beecroft, A.J. (2008). Nine Fragments in Search of an Author: Poetic Lines Attributed to Terpander. The Classical Journal 103 (3), (pp. 225-241).

Bierl, A. (2016) 'All You Need is Love': Some Thoughts on the Structure, Texture, and Meaning of the Brothers Song as well as on Its Relation to the Kypris Song (P. Sapph. Obbink). In A. Bierl \& A. Lardinois (Eds.) The Newest Sappho: P. Sapph. Obbink and P. GC inv. 105, frs. 1-4. Leiden: Brill. (pp. 303-337).

Boterf, N. (2012). Lyric Cities: Poets, Performance, and Communities [Unpublished doctoral thesis]. Stanford: Stanford University.

Bowie, A. (1981). The Poetic Dialect of Sappho and Alcaeus. Salem: The Ayer Company. Bowie, E. (2009). Wandering poet, archaic style. In R. Hunter \& I. Rutherford (Eds.) Wandering Poets: Travel and Locality in Greek Poetic Culture. Cambridge: Cambridge University Press. (pp. 105-136).

Bowie, E. (2016). How Did Sappho's Songs Get into the Male Sympotic Repertoire? In A. Bierl \& A. Lardinois (Eds.) The Newest Sappho: P. Sapph. Obbink and P. GC inv. 105, frs. 1-4, Leiden: Brill. (pp. 148-164).

Bowie, E. (2021). Sappho in Imperial Greek Literature. In P. Finglass \& A. Kelly (Eds.) The Cambridge Companion to Sappho. Cambridge: Cambridge University Press. (pp. 303-319).

Broger, A. (1996). Das Epitheton bei Sappho und Alkaios. Eine sprachwissenschaftliche Untersuchung. Innsbruck: Institut für Sprachwissenschaft der Universität Innsbruck.

Bundy, E.L. (2006) [first published in 1962]. Studia Pindarica. eScholarship Repository, University of California. http://repositories.cdlib.org/ucbclassics/bundy 
Caciagli, S. (2016). Sappho Fragment 17: Wishing Charaxos a Safe Trip?. In A. Bierl \& A. Lardinois (Eds.) The Newest Sappho: P. Sapph. Obbink and P. GC inv. 105, frs. 1-4. Leiden: Brill. (pp. 424-448).

Cairns, F. (2007). Generic Composition in Greek and Roman Poetry. Ann Arbor: Michigan Classical Press.

Calame, C. (1997) [French edition: 1977]. Choruses of young women in ancient Greece: their morphology, religious role, and social function. Lanham: Rowman \& Littlefield.

Carey, C. (2011). Alcman: from Laconia to Alexandria. In L. Athanassaki \& E. Bowie (Eds.) Archaic and Classical Choral Song. Performance, Politics and Dissemination. Berlin: Walter de Gruyter. (pp. 437-460).

Cassio, A.C. (2009). The Language of Hesiod and the Corpus Hesiodeum. In F. Montanari, A. Rengakos, C. Tsagalis (Eds.) Brill's Companion to Hesiod (pp. 179202). Leiden: Brill.

Colvin, S. (2007). The Dance of the Islands. Insularity Networks, the Athenian Empire and the Aegean World. Oxford: Oxford University Press.

Colvin, S. (2014). A Brief History of Ancient Greek. Chichester: Wiley-Blackwell.

Constantakopoulou, C. (2005). Proud to Be an Islander: Island Identity in Multi-Polis Islands in the Classical and Hellenistic Aegean. Mediterranean Historical Review, 20 (1), (pp. 1-34).

Coo, L. (2021). Sappho in Fith- and Fourth-Century Greek Literature. In P. Finglass \& A. Kelly (Eds.) The Cambridge Companion to Sappho (pp. 263-276). Cambridge: Cambridge University Press.

Cook, R.M. (1997). Greek Painted Pottery. London: Routledge.

D’Alessio, G. B (2009b). Defining local identities in Greek lyric poetry. In R. Hunter \& R. Rutherford (Eds.) Wandering Poets: Travel and Locality in Greek Poetic Culture (pp. 137-167). Cambridge: ambridge University Press.

D’Alessio, G. B. (2009a). Language and Pragmatics. In F. Budelmann (Ed.) The Cambridge Companion to Greek Lyric Poetry. Cambridge: Cambridge University Press. (pp. 114-129).

D’Alessio, G. B. (2016). Bacchylides' Banquet Songs. In V. Cazzato, D. Obbink, E. Prodi (Eds.) The Cup of Song: Studies on Poetry and the Symposion. Oxford: Oxford University Press. (pp. 63-84). 
D'Alessio, G. B. (2018). Fiction and Pragmatics in Ancient Greek Lyric: The Case of Sappho. In F. Budlemann \& T. Phillips (Eds.) Textual Events: Performance and the Lyric in Early Greece (pp. 31-62). Oxford: Oxford University Press.

De Vos, M. (2014). From Lesbos She Took Her Honeycomb: Sappho and the 'Female Tradition' in Hellenistic Poetry. In C. Pieper \& J. Ker (Eds.) Valuing the Past in the Greco-Roman World. Proceedings from the Penn-Leiden Colloquia on Ancient Values VII. Leiden: Brill. (pp. 410-434).

Edwards, M.W. (1988). Homer and Oral Tradition: The Formula, Part II. Oral Tradition, 3/1-2, (pp. 11-60).

Edwards, M.W. (1986). Homer and Oral Tradition: The Formula, Part I. Oral Tradition, 1/2, (pp. 171-230).

Ellis-Evans, A. (2019). The Kingdom of Priam. Lesbos and the Troad between Anatolia and the Aegean. Oxford: Oxford University Press.

Ferrari, F. (1986). Formule Saffiche e Formule Omeriche. Annali della Scuola Normale Superiore di Pisa. Classe di Lettere e Filosofia, Serie III, 16 (2), (pp. 441-447).

Foley, J. M. (1993). Traditional Oral Epic. The Odyssey, Beowulf, and the SerboCroatian Return Song. Berkeley: University of California Press.

Garner, R. S. (2011a). Traditional Elegy. The Interplay of Meter, Tradition, and Context in Early Greek Poetry. Oxford: Oxford University Press.

Garner, R. S. (2011b). Oral Tradition and Sappho. Oral Tradition, 26 (2), (pp. 413-444).

Giannini, P. (1973). Espressioni formulari nell'elegia greca arcaica. Quaderni Urbinati di Cultura Classica, 16, (pp. 7-78).

Hackstein, O. (2010) The Greek of Epic. In E. J. Bakker (Ed.) A Companion to the Ancient Greek Language. Chichester: Blackwell Publishing. (pp. 401-422).

Hadjimichael, T.A. (2019). The Emergence of the Lyric Canon. Oxford: Oxford University Press.

Hainsworth, J.B. (1968). The Flexibility of the Homeric Formula. Oxford: Clarendon Press.

Herington, J. (1985). Poetry into Drama: Early Tragedy and the Greek Poetic Tradition. Berkeley: University of California Press.

Hinge, G. (2006). Die Sprache Alkmans. Wiesbaden: Dr. Ludwig Reichert Verlag. 
Mare Nostrum, ano 2021, v. 12, n. 2

Hoekstra, A. (1965). Homeric modifications of formulaic prototypes. Studies in the development of Greek epic diction. Amsterdam: N. V. Noord-Hollandsche Uitgevers Maatschappij.

Hooker, J. T. (1977). The Language and the Text of the Lesbian Poets. Innsbruck: Innsbrücker Beiträge zur Sprachwissenschaft.

Horrocks, G. (1997). Homer's Dialect. In I. Morris \& B. Powell (Eds.) A New Companion to Homer. Leiden: Brill. (pp. 193-217).

Horrocks, G. (2010). Greek: a history of the language and its speakers. Chichester: Wiley-Blackwell.

Hunter, R. (2021). Sappho and Hellenistic Poetry. In P. Finglass \& A. Kelly (Eds.) The Cambridge Companion to Sappho. Cambridge: Cambridge University Press. (pp. 277-289).

Janko, R. (1982). Homer, Hesiod and the Hymns. Diachronic development in epic diction. Cambridge: Cambridge University Press.

Jebb, R.C. (Ed.) (1905). Bacchylides: the poems and the fragments. Cambridge: Cambridge University Press.

Kelly, A. (2007). A Referential Commentary to Homer, Iliad VIII. Oxford: Oxford University Press.

Kelly, A. (2021). Sappho and Epic. In P. Finglass \& A. Kelly (Eds.) The Cambridge Companion to Sappho. Cambridge: Cambridge University Press. (pp. 53-64).

Kim, L. (2010). Homer Between History and Fiction in Greek Imperial Literature. Cambridge: Cambridge University Press.

Kim, L. (2014). 'Archaizing and Classicism in the Literary Historical Thinking of Dionysius of Halicarnassus. In C. Pieper \& J. Ker (Eds.) Valuing the Past in the Greco-Roman World. Leiden: Brill. (pp. 357-387)

Liberman, G. (2002). Alcée. Fragments. Tomes I e II. Paris: Les Belles Lettres.

Littmann, E. (1916). Sardis. Publications of the American Society for the Excavation of Sardis. Volume VI. Lydian Inscriptions. Leiden: Brill.

Lord, A.B. \& Lord, M. L. (Ed.) (1995). The Singer Resumes the Tale. Ithaca, NY and London: Cornell University Press.

Malkin, I. (2011). A Small World. Networks in the Ancient Mediterranean. Oxford: Oxford University Press. 
Mason, H. J. (1993). Mytilene and Methymna: quarrels, borders and topography. Echos du Monde Classique/Classical Views, 37 (12), (pp. 225-250).

Meyerhoff, D. (1984). Traditioneller Stoff und Individuelle Gestaltung. Untersuchungen zu Alkaios und Sappho. Hildesheim: Olms-Weidmann.

Mitchell, E.A. (1984). The Laconian Dialect [Unpublished doctoral thesis]. Edinburgh: University of Edinburgh. https://era.ed.ac.uk/handle/1842/6724

Morgan, L. (2021). Sappho at Rome. In P. Finglass \& A. Kelly (Eds.) The Cambridge Companion to Sappho. Cambridge: Cambridge University Press. (pp. 290-302).

Nagler, M. N. (1974). Spontaneity and Tradition. A Study in the Oral Art of Homer. Berkeley: University of California Press.

Nagy, G (1990). Pindar's Homer: The Lyric Possession of an Epic Past. Baltimore, London: John Hopkins University Press. http://nrs.harvard.edu/urn3:hul.ebook:CHS_Nagy.Pindars_Homer.1990

Nagy, G (2007). Did Sappho and Alcaeus Ever Meet? Symmetries of Myth and Ritual in Performing the Songs of Ancient Lesbos. In A. Bierl, R. Lammle, K. Wesselmann (Eds.) Literatur Und Religion: Wege zu einer mythisch-rituellen Poetik bei den Griechen Berlin: Walter de Gruyter. (pp. 211-269).

Nagy, G (2016) A Poetics of Sisterly Affect in the Brothers Song and in Other Songs of Sappho. In A. Bierl \& A. Lardinois (Eds.) The Newest Sappho: P. Sapph. Obbink and P. GC inv. 105, frs. 1-4. Leiden: Brill. (pp.449-492).

Nagy, G. (1974). Comparative Studies in Greek and Indic Metre. Cambridge, MA: Harvard University

Press.http://nrs.harvard.edu/urn3:hul.ebook:CHS_Nagy.Comparative_Studies_in_ Greek_and_Indic_Meter.1974.

Parry, M. \& Parry, A. (Ed.) (1971). The Making of Homeric Verse: The Collected Papers of Milman Parry. Oxford: Oxford University Press.

Pavúk, P. (2008, June 12) Grey Wares as a Phenomenon. Aegean and Balkan Prehistory. http://www.aegeobalkanprehistory.net/index.php?p=article\&id_art=5.

Power, T. (2010). The Culture of kitharôidia. Cambridge, MA: Harvard University Press. Power, T. (2019). Sappho’s Parachoral Monody. In M. Foster, L. Kurke. N. Weiss (Eds.) Genre in Archaic and Classical Greek Poetry: Theories and Models. Leiden: Brill. (pp. 82-108). 
Mare Nostrum, ano 2021, v. 12, n. 2

Rissman, L. (1983). Love as War: Homeric Allusion in the Poetry of Sappho. Königstein/Ts.: Anton Hain.

Robert, L. (1960). Recherches Épigraphiques. Revue des Études Anciennes, 63 (3-4), (pp. 276-361).

Rösler, W. (1980). Dichter und Gruppe. Eine Untersuchung zu den Bedingungen und zur historischen Funktion früher griechiescher Lyrik am Beispiel Alkaios. München: Wilhelm Fink.

Russo, J. (1997). The Formula. In I. Morris \& B. Powell (Eds.) A New Companion to Homer. Leiden: Brill. (pp. 238-260).

Rutherford, I. (2013). State pilgrims and sacred observers in Ancient Greece. A study of Theōriā and Theōroi. Cambridge: Cambridge University Press.

Rutherford, I. (2001). Pindar's Paeans: A Reading of the Fragments with a survey of the Genre. Oxford: Oxford University Press.

Sacks, R. (1987). The Traditional Phrase in Homer: Two Studies in Form, Meaning and Interpretation. Leiden: Brill.

Schaus, G. P. (1992). Archaic Imported Fine Wares from the Acropolis, Mytilene. Hesperia: The Journal of the American School of Classical Studies at Athens, 61 (3), (pp. $355-374)$.

Silk, M. (2009). The Invention of Greek. In A. Georgakopoulou \& M.S. Silk (Eds.) Standard languages and language standards: Greek, past and present. London: Routledge. (pp. 3-31).

Silk, M. (2010). The Language of Greek Lyric Poetry. E. J. Bakker (Ed.) A Companion to the Ancient Greek Language. Chichester: Blackwell Publishing. (pp. 424-440).

Spencer, N. (1995). Early Lesbos between East and West: A 'Grey Area' of Aegean Archaeology. The Annual of the British School at Athens, 90. (pp. 269 -306).

Swain, S. (1996). Hellenism and Empire. Language, Classicism, and Power in the Greek World AD 50-250. Oxford: Oxford University Press.

Swift, L. A. (Ed.) (2019). Archilochus. The Poems. Oxford: Oxford University Press.

Swift, L. A. (2010). The Hidden Chorus. Echoes of Genre in Tragic Lyric. Oxford: Oxford University Press.

Thomas, R. (2021). Sappho's Lesbos. In P. Finglass \& A. Kelly (Eds.) The Cambridge Companion to Sappho. Cambridge: Cambridge University Press. (pp. 22-35). 
Tribulato, O. (2010). Literary Dialects. In E. J. Bakker (Ed.) A Companion to the Ancient Greek Language. Chichester: Blackwell Publishing. (pp. 388-400).

Voigt, E.-M. (1971). Sappho et Alcaeus. Fragmenta. Amsterdam: Athenaeum / Polak \& Van Gennep.

West, M. L. (1973). Greek Poetry 2000-700 B.C. The Classical Quarterly, 23 (2). (pp. 179-192).

West, M. L. (2003). Phrygian Metre. Kadmos, 42. (pp. 77-86).

West, M. L. (1972). Lydian Metre. Kadmos, 11 (2), pp. 165-175.

West, M. L. (1982). Greek Metre. Oxford: Oxford University Press.

West, M. L. (2002). The View from Lesbos. In M. Reichel \& A. Rengakos (Eds.) Epea Pteroenta. Beiträge zur Homerforschung. Festschrift für Wolfgang Kullmann. Stuttgart: Franz Steiner. (pp. 207-219).

West, M. L. (Ed.) (1966). Hesiod. Theogony. Oxford: Clarendon Press.

Yatromanolakis, D. (2007) Sappho in the Making. The Early Reception. Washington, D.C.: Centre for Hellenic Studies. 
Mare Nostrum, ano 2021, v. 12, n. 2

\section{Insularidade E A Posição Única Da Canção Eólica Na Poesia Grega A RCAICA}

Tadeu Andrade

RESUMO

A poesia grega arcaica não era um fenômeno unitário: áreas diversas desenvolveram gêneros diferentes, ainda que interrelacionados. Este artigo aborda a posição única da canção eólica na tradição grega. Primeiramente, aponta a recepção algo ambígua de Safo e Alceu pelos antigos. Em segundo lugar, mostra como seu corpus, frente ao restante da poesia grega, demonstra um padrão de comunicação e independência. Discutem-se mais detalhadamente as fórmulas poéticas eólicas, em que essa tendência se torna especialmente evidente. Enfim, o artigo propõe-se discutir a geografia insular de Lesbos como uma das causas para a singularidade de sua poesia.

PALAVRAS-CHAVE

Insularidade, lírica grega, poesia lésbia, oralidade, fórmulas. 